\title{
POLICY AS MYTH AND CEREMONY? THE GLOBAL SPREAD OF STOCK EXCHANGES, 1980-2005
}

\author{
KLAUS WEBER \\ Northwestern University \\ GERALD F. DAVIS \\ University of Michigan \\ MICHAEL LOUNSBURY \\ University of Alberta
}

\begin{abstract}
We examine the antecedents and consequences in developing countries of creating a national stock exchange, a core technology of financial globalization. We study local conditions and global institutional pressures in the rapid spread of exchanges since the 1980s and examine how conditions at the point of adoption affected exchanges' subsequent vibrancy. Little prior research connects the process of diffusion with the operational performance of adopted policies. We find that international coercion was associated with more ceremonial adoption but that, contrary to expectations common in institutional research, contagion processes via peer groups and normative emulation of prestigious actors enhanced vibrancy.
\end{abstract}

Economic globalization provides a generative context in which to consider the policy implications of organizational theory and research. Globalization creates both opportunities and challenges for countries on the periphery of the world economy. The central question for policy makers is what structures and institutions they should adopt to promote economic and social vibrancy. Notably, waves of alternative theories and associated packages of reforms have swept over the globe in recent decades. Observing this process of global diffusion (and often abandonment) of policies and practices, Meyer, Boli, Thomas, and Raminrez (1997) extended analyses of myth and ceremony at the organization level to the nation-state in their "world society" approach. A core idea in this work is that coercion and mimicry of peers or competitors, typically based in a substrate of network ties, often prompt adoption (Henisz, Zelner, \& Guillén, 2005; Polillo \& Guillén, 2005). Yet the study of adoption has been largely decoupled from the study of effectiveness. After states adopt these practices, what

We thank Mauro Guillén and three anonymous $A M J$ reviewers for their insights and questions, and Chris Marquis, Mark Mizruchi, Huggy Rao, and Sid Tarrow for comments on drafts. We also thank Simone Polillo, David Strang, and Chang Kil Lee for sharing data and advice on measurement, and Andrei Jirnyi for statistical programming assistance. The study benefited from funding by the William Davidson Institute at the University of Michigan. happens next? Researchers know who adopts and why but have much less sense of when an adopted practice works as expected, and how conditions at the time of adoption influence effectiveness.

Findings at the organizational level may apply at the country level. Some practices work as predicted, or their implementation may improve over time with learning. The multidivisional form ("Mform") of corporate organization (Williamson, 1975) has been an example. Other practices are adopted in earnest but fail to live up to their promise; many cases of the adoption of total quality management (TQM) evidence the latter (Zbaracki, 1998). Organizations adopt some practices cynically, with little intention of following through, as in the case of many corporations announcing stock buy-back plans that they never implement (Westphal \& Zajac, 2001). Still other practices are adopted ceremonially, as a gesture of compliance, yet nonetheless create real change: companies may create an office of equal employment opportunity as a symbol to fend off lawsuits, but once in place such offices can actually change employment outcomes (Sutton \& Dobbin, 1996). The implication of the cited studies is that why one adopts may affect how one adopts, and how effectively.

This study is one of the first to simultaneously examine the causes and consequences of adoption. We draw on the world society variant of new institutional theory (Meyer et al., 1997) to examine the spread of stock exchanges around the world and their vibrancy in terms of growth in size (equities 
listed and market capitalization). Stock exchanges spread widely around the world during the 1980s and 1990s. In 1980, only 59 countries had exchanges, but over the next 25 years, 58 more opened their first indigenous stock exchanges. Table 1 lists the countries that created markets between 1960 and 2005, and Figure 1 graphs the prevalence of markets among independent states over the period 1800-2005.

Stock exchanges provided a particularly useful context for our study because they were adopted out of diverse motivations and showed great variation in subsequent performance. Exchanges in former Soviet bloc countries were typically created as mechanisms for mass privatization (e.g., Spicer, 2002); other countries, such as Guatemala and Uganda, created them de novo. It is also clear that some exchanges thrived while others floundered. Trading at the Swaziland Stock Exchange, founded by a former World Bank executive in 1990, was limited to a total of 50 transactions for the five listed equities in 2000, but the Shanghai Stock Exchange rapidly achieved valuations that rivaled those of the world's largest developed economies.

We ask two questions: Why did some countries but not others adopt their initial post-World War II stock exchanges between 1980 and 2005? And what made for success? Our contributions are two. First, we seek to draw out the implications for international policy makers of new institutional theory. Second, we contribute to the study of institutions by examining how the sources and consequences of new practices are linked, an undertheorized and underresearched problematic. Empirically, we found that practices adopted through a process of mimesis were more likely to thrive, but those adopted owing to coercive processes were less likely to do so.

\section{STOCK MARKETS AND ECONOMIC DEVELOPMENT}

Stock exchanges are a central component of the contemporary global economy, as cross-border financial flows have vastly expanded and equities in emerging markets have attracted substantial attention from globally oriented institutional investors. But this is a relatively recent phenomenon. Formal stock exchanges in the immediate postwar era were largely limited to countries with sufficiently large incomes to generate domestic savings. Of the 49 countries with stock exchanges in 1950, 24 were located in Europe, and 13 were in current or former British colonies such as the United States, Canada, and Australia (Goetzmann \& Jorion, 1999). Stock exchanges, in short, were widely legitimate and
TABLE 1

Countries Creating Stock Markets between 1960 and 2005

\begin{tabular}{|c|c|}
\hline Year & Countries \\
\hline 1960 & Nigeria \\
\hline 1961 & Taiwan \\
\hline 1962 & - \\
\hline 1963 & - \\
\hline 1964 & Malaysia \\
\hline 1965 & - \\
\hline 1966 & Iran \\
\hline 1967 & - \\
\hline 1968 & Jamaica \\
\hline 1969 & Ecuador, Tunisia \\
\hline 1970 & - \\
\hline 1971 & - \\
\hline 1972 & - \\
\hline 1973 & - \\
\hline 1974 & Cote d'lvoire, Thailand \\
\hline 1975 & - \\
\hline 1976 & Jordan, Costa Rica \\
\hline 1977 & Indonesia, Paraguay \\
\hline 1978 & - \\
\hline 1979 & Bolivia \\
\hline 1980 & Fiji \\
\hline 1981 & Trinidad and Tobago \\
\hline 1982 & - \\
\hline 1983 & - \\
\hline 1984 & Saudi Arabia, Kuwait \\
\hline 1985 & Iceland \\
\hline 1986 & - \\
\hline 1987 & Bahrain, Barbados \\
\hline 1988 & Oman \\
\hline 1989 & Ghana, Mauritius, Guatemala, Yugoslavia \\
\hline 1990 & $\begin{array}{l}\text { Honduras, China, Soviet Union, Malta, } \\
\text { Swaziland, Panama, Hungary }\end{array}$ \\
\hline 1991 & Croatia, Poland, Bulgaria \\
\hline 1992 & $\begin{array}{l}\text { Czechoslovakia, Ukraine, Namibia, Lithuania, } \\
\text { Mongolia, El Salvador }\end{array}$ \\
\hline 1993 & Armenia, Latvia, Bhutan, Cyprus \\
\hline 1994 & Botswana, Uzbekistan, Nepal \\
\hline 1995 & $\begin{array}{l}\text { Kyrgyz Republic, Malawi, Moldova, Zambia, } \\
\text { Macedonia, Romania, Estonia }\end{array}$ \\
\hline 1996 & Lebanon \\
\hline 1997 & Uganda, Kazakhstan, Qatar \\
\hline 1998 & Tanzania \\
\hline 1999 & Georgia, Algeria \\
\hline 2000 & $\begin{array}{l}\text { United Arab Emirates, Papua New Guinea, } \\
\text { Azerbaijan, Vietnam, Bahamas }\end{array}$ \\
\hline 2001 & - \\
\hline 2002 & Maldives \\
\hline 2003 & Guyana \\
\hline 2004 & Iraq \\
\hline 2005 & Cape Verde \\
\hline since 2005 & $\begin{array}{l}\text { Suriname (2006), Libya (2007), Syria (2009); in } \\
\text { preparation as of 2009: Cambodia, Lao, } \\
\text { Albania, Afghanistan }\end{array}$ \\
\hline
\end{tabular}

institutionalized, but their policy applicability was largely seen as limited to wealthy countries in the "global north."

Given the low level of indigenous savings on which to draw in developing nations, and limited 
FIGURE 1

Prevalence of Stock Markets among Independent Modern Countries, 1800-2005

(a) Number of Independent States and Stock Exchanges

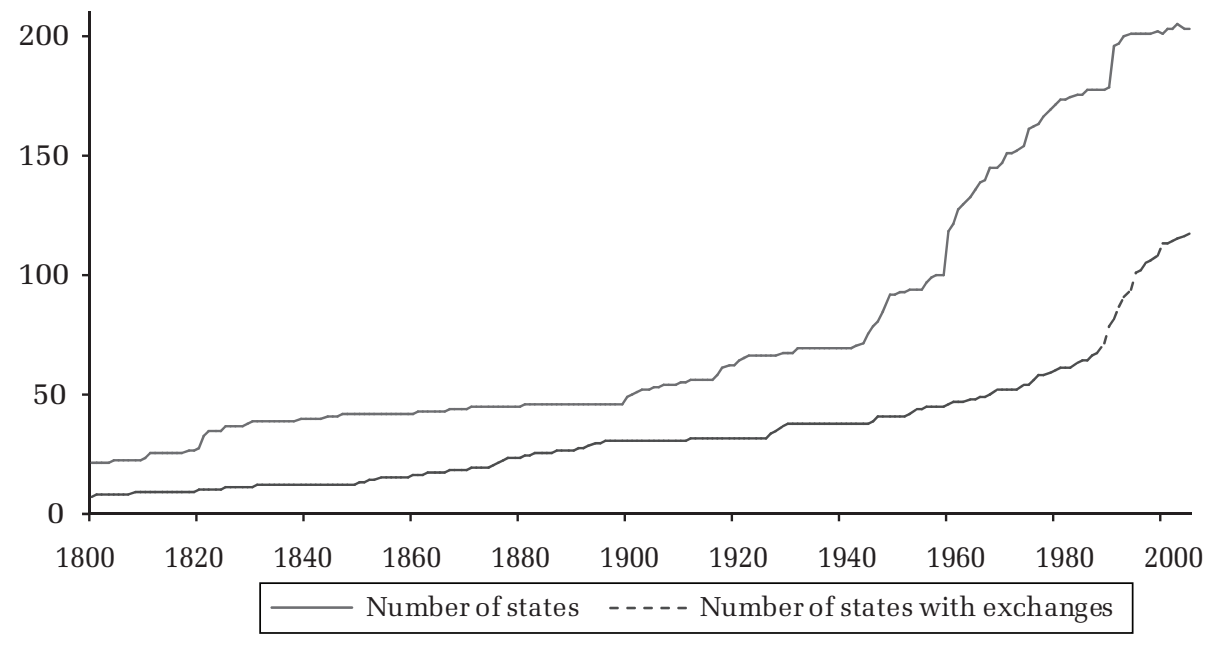

(b) Percentage of Independent States with Exchanges

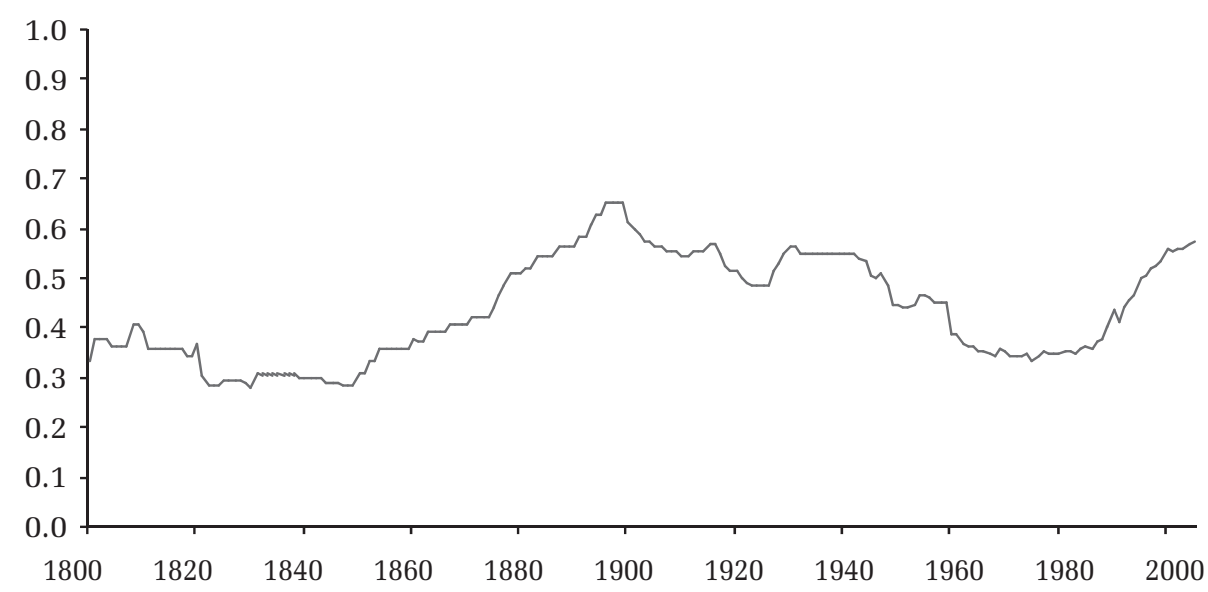

(c) Number of Adopting States, Four-Year Moving Average

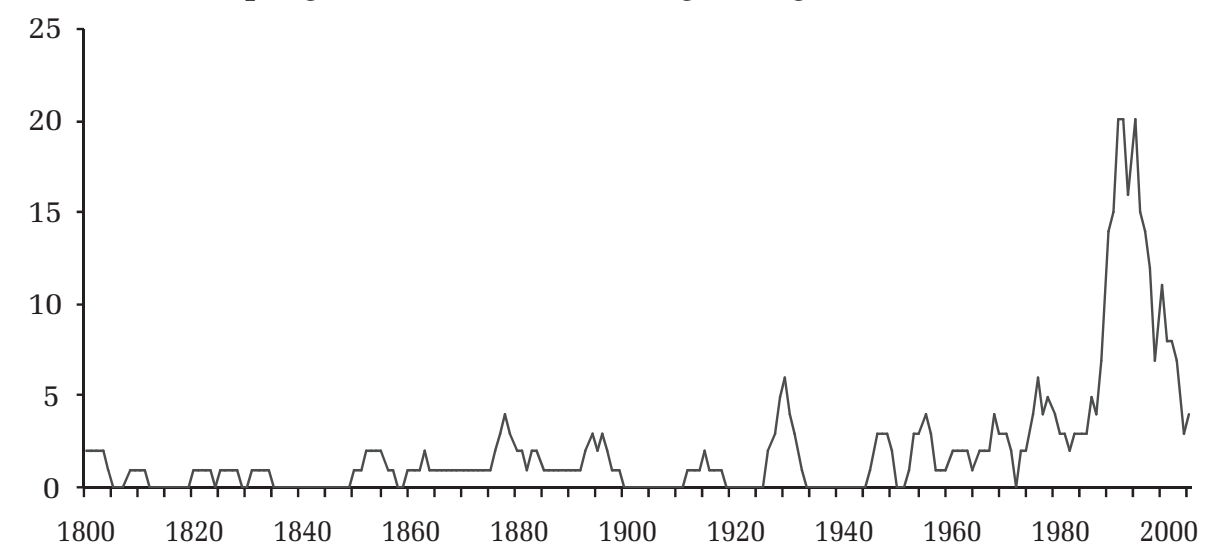

infrastructures for channeling foreign capital, stock markets played little role in their economic development activity and policy discourse prior to the mid 1980s. Rather, capital for economic development came from other sources, according to the theories of development dominant at the time (McMichael, 1996). In the 1950s and 1960s, state-tostate foreign aid was the dominant form of capital flow from advanced industrial countries to developing economies (Armijo, 1999). During the 1970s, 
long-term lending by banks to governments in developing countries increased dramatically and nearly matched the level of foreign aid. Aggressive bank lending ended abruptly in 1982, when Mexico suspended external debt service and signaled the beginning of a debt crisis throughout the developing world (Manzocchi, 1999). The rest of the 1980s has been called the "lost decade" in development, as private financial flows to developing economies contracted substantially.

In response to the perceived failures of the development project and to the 1980s debt crisis, the globalization project (McMichael, 1996) theorized and promulgated a market-based strategy of economic development. Rather than relying on aid or bank-to-state lending, the new model relied on private investment flows to the private sector in developing economies. The International Monetary Fund (IMF) and the World Bank facilitated the spread of this model as part of a package of "structural adjustment" reforms during the 1980s, as did Antoine Van Agtmael (1984), an economist at the International Finance Corporation who coined the phrase "emerging markets" as an appealing alternative to "third world." This shift in thinking legitimated stock markets, already an institutionalized policy solution to managing capital markets in developed countries, as a solution to the different problem of economic development.

Initially, portfolio investment in low-income countries was inconsequential. In the late 1980s, however, portfolio investment in the newly christened emerging markets began to flow in earnest, as investors were attracted by the returns available from high-growth economies. The late 1980s and early 1990s saw a wave of market liberalizations that allowed foreign investors to buy domestic equities (Bekaert, Harvey, \& Lundblad, 2005), and by the mid 1990s, the trickle of foreign investment became a torrent as emerging market funds became staples in the portfolios of institutional investors in advanced economies. The World Bank reported this: "In 1986 there were 19 emerging market country funds and 9 regional or global market funds. By 1995 there were over 500 country funds and nearly 800 regional and global funds. The combined assets of all closed- and open-end emerging market funds increased from $\$ 1.9$ billion in 1986 to $\$ 10.3$ billion in 1989 to $\$ 132$ billion at the middle of 1996 " (1997: 16).

The new theory of development is reflected in the World Bank's World Development Report for 2000. The theory, in brief, is that the creation of "well-regulated" financial markets open to foreign investors provides the surest path to rapid economic development. At the receiving end, busi- nesses in low-income countries gain direct access to the enormous stocks of private capital generated in industrialized countries. Rather than having to rely on aid and loans mediated by political organizations, they receive capital directly from private investors. Bypassing potentially inefficient or corrupt government structures frees local entrepreneurial potential and accelerates economic growth. Policy makers and corporate managers are thus encouraged to make future-oriented decisions about the governance of their economic systems. This system also offers a unique opportunity for capitaldeprived developing countries that can convince investors about the future prospects of their economies. Rather than wait for domestic capital to form in a slow process, they can borrow from or sell equity to foreign savers to speed development and so join the global economy much more quickly. Moreover, stock markets generate a wealth of intelligence through the operation of the price system, which helps guide decisions of both managers and investors. The benefits to investors are rooted in prospective growth rates unattainable in advanced economies and high returns matching the risks involved.

The "financial market theory of development" has found support in several academic studies (for a concise review of the evidence, see chapter 3 of the 2000 World Development Report). Filer, Hanousek, and Campos (1999), for instance, reported that stock market activity enhanced economic growth in low- and middle-income countries, in keeping with a number of studies by Levine and his coauthors on the beneficial effects of financial development (Levine, 1998). But if stock markets are so manifestly beneficial, the appropriate question is perhaps not, "Why have they spread so quickly in the recent past?" but "Why do only half the world's economies have them?" The financial market theory of development implies that stock markets will enhance economic growth to the extent that they are embedded in an institutional matrix that ensures that their signals guide decision makers toward growth opportunities. But countries vary substantially in the extent to which they provide hospitable climates for financial markets. Thus, the critical question for understanding the uneven spread and performance of stock exchanges is, What are the conditions that facilitate or inhibit the creation and development of stock exchanges in particular countries?

\section{THE POLICY PROCESS OF CREATING AN EXCHANGE}

We regard the creation and development of a stock exchange as a country-level policy decision. 
This is to emphasize that although government policy makers are essential to the creation of a stock exchange, the process involves other agencies and interest groups and thus requires private and state actors to work in concert (e.g., Lindblom \& Woodhouse, 1993). These actors create political impetus and a legal basis and also supply private capital and develop market infrastructure for the operation of an exchange. We thus treat having a stock exchange as an attribute of a country that emerges from a distributed policy making and implementation process involving a wide set of participants. We use the term "policy makers" to refer to this larger group.

An assumption of our theoretical model is that distributed policy making at the country level is broadly analogous to distributed decision making in organizations. The rationale for this assumption follows from how institutional theorists have depicted collective decision-making processes. States are a particular type of organization. Their policies reflect a resolution of conflicts among the diverse interests of their constituents inside and out. Indeed, some foundational works on organizations were written by political scientists drawing explicitly on models of coalitional politics (Cyert \& March, 1963; March \& Simon, 1958), and a widely read account of the Cuban missile crisis built directly on this model of organizations (Allison, 1971). Dozens of subsequent studies in political science followed Allison in applying organization theory to the operations of states (see Davis and Powell [1990] for a review). Insights from opensystems models of organizations also apply. States and other organizations face an environment of other organizations with which they are more or less interdependent, as well as internal and external pressures for legitimacy. States learn from the experiences of other states that have dealt with similar problems, and their leadership may draw on successful "alters." Thus, there is reason to expect that findings at the organization level will provide insight into country-level policy.

\section{Policy Adoption}

Creating a new stock market requires that policy makers have the motivation to pursue this change and the skill to realize it. The many potential triggers for creating a stock exchange broadly relate to the attributes of a country and to conditions external to it. Internal country attributes include a country's level of economic development, political system and ideology, and prior institutional endowment, all of which are believed to motivate and enable internally focused policy makers to adopt solutions consistent with these factors. Recent research has shown a number of such internal features to be associated with more vibrant stock markets and thus suggests several prompts to adoption. One study directly examined the correlates of having an exchange in December 1998 (Clayton, Jorgenson, \& Kavajecz, 2006). Countries with a common law tradition, as opposed to those with a civil law tradition, tend to have superior protections for minority shareholders and were thus more likely to have markets in the first place (cf. La Porta, Lopez-de-Silanes, Shleifer, \& Vishny, 1998, 1999a, 1999b). Countries with bigger economies and those with greater openness to trade and investment flows were more likely to have exchanges than those with smaller and more closed economies.

Such cross-sectional findings are subject to a number of limitations. Many of the exchanges examined had been in operation for decades, if not centuries, and there was great potential for reverse causality, with the creation of markets preceding openness to trade and investment as well as, presumably, economic growth. Moreover, many features associated with larger stock markets are fixed or, at the minimum, slow to change. We do not observe widespread shifts from civil law to common law, from Protestantism to Catholicism, or from being a former French colony to being a former British colony. To explain the recent surge of adoptions requires a more dynamic and more contextual account of the policy process.

A number of country-level practices and policies rooted in economic and political liberalism spread rapidly during roughly the same time period as stock exchanges, and research has documented that diffusion-relying on the prior experiences of other adopters-is behind much of this dynamic. Anecdotes and systematic evidence suggest that policy makers consciously assess the expectations and prior policy choices of other countries and of global elites when contemplating policy changes (Simmons, Dobbin, \& Garrett, 2006). When considering the implementation of reforms, such as privatization of government-owned industries, or public sector downsizing, policy makers rely on templates obtained from the international professional policy elite, site visits, bilateral meetings, membership in common associations, benchmarking of "best practices," and explicit emulation of the strategies of successful and prestigious predecessors. Other countries, professional communities, and prominent international agencies, such as the IMF and World Bank, influence the motivation for and skillfulness of policy implementation: Policy makers are concerned about the legitimacy of their decisions in the eyes of international as much as local 
audiences, and they draw on knowledge and resources outside as well as inside their countries. Recent sociological work has distinguished a number of mechanisms at work behind diffusion (Lee \& Strang, 2006). Each highlights different rationales for policy adoption and different prospects for success based on the international context of policy making.

Simmons, Dobbin, and Garrett (2006) described four mechanisms of international diffusion: coercion, competition, learning, and emulation. Coercion occurs when powerful outsiders (states or other actors) impose their models on the policy makers of dependent countries. Both the motivation and the knowledge for adopting a policy come from outside the country. In the case of economic policy, the IMF is particularly implicated in moreor-less coercive efforts at policy reform. This mechanism suggests that states are more likely to adopt a policy to the extent that they are dependent on coercive actors favoring that policy and that their internal motivation and skill for adoption are limited. Competition occurs when states adopt a policy thought to provide an advantage relative to competitors, or to avoid a disadvantage. The motive for adoption is social comparison coupled with rivalry; rivalry to some extent impedes the direct transfer of knowledge and resources. This mechanism suggests that states are prone to adopting practices that their economic competitors have previously implemented. Learning implies that policy makers learn not only from their own experience but also from that of others. They attend particularly to the actions of proximate alters, such as peers with whom they enjoy close contact. This proximity enables the transfer of ideas and knowledge, which internalizes the motivation and skill for policy change into a country's policy-making process. Learning is indicated when adoption follows from prior adoptions by those in closest proximity (e.g., geographic, cultural, or economic). Although the concept of learning is sometimes more narrowly applied to mimicking practices that have already proven successful (vicarious learning), most learning theorists have pointed out that this is overly restrictive and ignores adaptive learning from proximate others prior to observable successes or when success is ambiguous and causally complex (Levitt \& March, 1996; Levy, 1994). Finally, emulation occurs when states adopt policies because they are normatively appropriate and have less regard for expected benefits. In emulation, policy makers look to prestigious others and follow the advice of elite professional communities in order to maintain their own status, even in the absence of detailed insight and resources for implementation. These four mechanisms are notably similar to the three mechanisms of isomorphism identified in neoinstitutional accounts as existing at the organization level: coercive, mimetic (including competition and learning), and normative forces (DiMaggio \& Powell, 1983).

\section{Policy Implementation}

The neoinstitutional literature further suggests that different reasons for adoption imply different levels of success at implementation, if success is defined as creating the results officially intended. Broadly, coercion should be followed by the least effective implementation, and learning should lead to the most effective implementation, with competition and emulation prompting more mixed levels of success. These differences derive from the extent to which motivations and skills for developing an adopted practice are internalized and embedded in a local setting. This internalization is needed for the ongoing activities that are required for successful implementation of a practice beyond its most formal elements. Early institutional research indicated that early adopters of a practice were in some sense sincere, but late adopters were motivated by unreflective mimicry; thus, earlier adopters might implement practices more forcefully than the mimics (e.g., Tolbert \& Zucker, 1983). But the success of late adopters can be quite variable. On the one hand, late adopters may be mere mimics, adopting an innovation because everyone else has and it has become taken for granted. On the other hand, later adopters can learn from the skill and experiences of early and contemporary adopters and implement policies more successfully.

Research on the spread of innovations among organizations supports the notion that both can be true. In a study of hospitals, Westphal, Gulati, and Shortell (1997) found that late adopters of TQM tended to implement the set of elements that had become most prevalent and that such conformity was associated with reduced efficiency but increased legitimacy. Kostova and Roth (2002) found that among international subsidiaries of a multinational, units located in places where quality practices were widespread implemented such practices more fully, but units more dependent on the parent company showed weaker implementation. They also found ceremonial adoption-adopting the practices without believing in their value-was prevalent in units facing regulatory pressures, indicating that coercion might lead to behavior without commitment. And Lounsbury (2001) showed that the majority of recycling programs adopted by universities were symbolic efforts that were under- 
resourced and staffed with ecologically ambivalent custodians, but that where local student movements had been mobilized, substantive recycling programs were created and staffed with full-time, ecologically committed managers. In the context of diffusion across countries, Zelner, Henisz, and Holburn (2009) argued that the implementation of the private ownership of electricity generation requires effort subsequent to the initial adoption stage and that partial renegotiations can be linked to local politics.

\section{Policy Adoption and Implementation}

Although institutional theorists have mostly focused on the formal adoption of practices, the more limited literature on implementation conveys the key insight that the success of policies and practices in terms of their implementation, maintenance, and ongoing development is intrinsically liked to the conditions of initial adoption. Initial conditions-the different motivations and skills that exist at adoption-provide a form of imprinting that shapes subsequent development and performance (Lounsbury \& Ventresca, 2002; Stinchcombe, 1965). Coercion is likely to lead to ceremonial adoption, because neither motivations nor skills are locally embedded in the process; learning, particularly through ties to prior adopters, is likely to lead to more substantive adoption, as motivations are internal and continuing flows of knowledge and experience allow the further development and refinement of a practice; and more equivocal levels of implementation will follow competition and emulation, as both are based on strong internal motivations for adoption but limited access to fine-grained skill and know-how.

In the case of post-World War II stock exchanges, all adopters are effectively late adopters. Stock exchanges have existed since the 17th century and were quite widespread among Western economies by the early years of the 20th. Almost by definition, then, countries that remained without exchanges were on the periphery or semiperiphery of the global economy. And by definition, the basic success of the practice was already proven. The creation of an exchange, like other national policy changes, can occur for diverse reasons and under diverse circumstances. The subsequent vibrancy of the market depends on a country's ability to fully implement, refine, and develop the market, and this subsequent success can be expected to vary according to the motivations and skills existing at the time of adoption. Adoption may be part of a package of reforms aimed at attracting foreign investment, and thus motivated and informed by the experience of neighbors or competitors, or it may be a perfunctory response to external pressuresone reform among several on a checklist aimed at documenting compliance with demands from third parties. In the first instance, we expect the exchange to receive ongoing support, but in the second, support may be perfunctory.

There are two boundary conditions to note about this account. First, the motivations of various policy makers are not directly observable. However, by observing both the antecedents of adoption and its consequences, one can infer the distinction between "sincere" and "ceremonial" adoption that has been central to the neoinstitutional perspective. Second, the success of a stock market is not entirely under the control of policy makers. Even true believers in the efficacy of markets cannot command a stock exchange to grow (although, conversely, it is possible to sabotage a market).

\section{HYPOTHESES: THE CREATION AND VIBRANCY OF STOCK MARKETS}

In the sections that follow, we focus first on the intranational factors promoting the creation and vibrancy of exchanges after 1980 and then focus on the international factors. We pair hypotheses about the antecedents of adoption with hypotheses about the effects of these antecedents on market growth.

\section{Prior Economic Development and Institutional Endowment}

Stock exchanges require a minimum level of national economic development to be feasible and economically useful. Both the size of an economy and the development of financial and economic infrastructure are relevant. Clayton et al. (2006) found that gross domestic product (GDP) per capita was significantly related to the presence of an exchange in 1998, and we anticipate that, although economic growth is potentially both a cause and a consequence of having an exchange, larger and wealthier economies are more likely to create exchanges than smaller and poorer ones. Countries with greater prior financial development are also more likely to create exchanges, as the development of banking sectors both supports and complements the operation of stock markets (Levine \& Zervos, 1998). Thus, countries with more expansive domestic credit are more likely to create exchanges. And economies that are already more open to trade are more likely to create exchanges. Clayton et al. (2006) found that measures of "economic freedom" compiled by the Heritage Founda- 
tion-particularly openness to trade and foreign investment-were correlated with the presence of an exchange. We therefore expected prior economic openness to be related to subsequent creation of exchanges. Although we did not derive formal hypotheses on these factors, we do include them as essential control measures.

The extent to which an exchange, once opened, becomes economically significant has also received attention in recent years (see La Porta, Lopez-deSilanes, Shleifer, and Vishny [2000] for a review). Some of the exchanges created since 1980 have remained miniscule relative to the sizes of the economies in which they are nested (for example, the market capitalization of all of Kazakhstan's public companies was roughly 0.2 percent of GDP in 1998), but others have become quite significant (the equivalent figure for Trinidad and Tobago was 61.5 percent). Given the varying motivations for adoption, it is then important from a policy perspective to investigate whether differences in the conditions of adoption relate to differences in exchange performance.

Scholars in the international comparative research tradition have emphasized the importance of a country's existing institutional background for its subsequent economic development. A historically evolved institutional matrix of cultural and political arrangements enables some but constrains other development directions (North, 1990). Researchers in corporate finance have identified a set of institutions particularly relevant in the context of financial markets, including a country's predominant religion; colonial legacies such as laws, language, and the education of national elites; and political system (La Porta \& Lopez-de-Silanes, 1998; La Porta et al., 1998, 2000). The common rationale behind these factors is that stock markets are more compatible with domestic institutions that support open participation and arms-length economic relationships.

A commercial culture derived from Protestantism, a democratic political system, and the legal and cultural protection of investors is therefore expected to foster the creation of market institutions (La Porta et al., 2000). The link between economic organization and religion goes back to Weber (1904/1958), who argued that particular strains of Protestantism facilitated the development of capitalism in the West following the Reformation. Protestantism has been positively associated with the viability of existing capital markets within nations, arguably because the relatively less hierarchical nature of Protestant tradition facilitates the horizontal ties useful for market transactions (La Porta et al., 1999b). The comprehensive influence of colonial powers exports institutional factors from metropolitan countries to former colonies. Note that colonial legacies encompass but go beyond legal systems (La Porta et al., 1999b). Not only laws, but also the training of local elites in metropolitan countries, administrative structures, and traditions shaped in the transition to statehood shape a country's subsequent policy orientation toward markets and private investment.

Given the rather different economic policy orientations of Britain and France in the colonial area (Dobbin, 1994), we would expect former British colonies to be more prone to create stock marketbased economic systems and former French colonies to be less inclined to do so and more likely to pursue more statist paths to development. Finally, financial markets are thought to be less amenable to direct influence by political authorities than alternative institutions. Rulers whose ideology is founded on authoritarian or socialist ideas should be suspicious of uncontrolled flows of capital in private hands and use their power to create different governance structures. Conversely, more democratic and less left-leaning regimes are expected to support the transparency and the potential dispersion of economic participation of public trading, as a check against the concentration of economic power and information. Because of their pervasiveness and relative permanence, we expected these factors to have a parallel influence on adoption and performance.

Hypothesis 1a. A country's historical conditions favoring investor-based systems (Protestantism, British colonial influence, political democracy, and nonsocialist ideology) increase the likelihood of stock exchange adoption.

Hypothesis 1b. Stock exchanges in countries favoring investor-based systems (characterized by Protestantism, British colonial influence, political democracy, and nonsocialist ideology) are larger than those in countries not favoring investor-based systems.

\section{Mechanisms of Diffusion}

Although internal conditions of economic and financial development, as well as an existing institutional endowment, are implicated in the creation and vibrancy of stock exchanges, they are not themselves sufficient to explain the dynamics of adoption. The spread of new exchanges, like the spreads of privatization, financial openness, and democracy, have all followed a classic S-shaped diffusion curve characteristic of contagion processes (Simmons et al., 2006). Whether through coercion, ob- 
servation, or direct contact, it is evident that each of these practices was adopted as part of an interdependent process among countries, not as the product of isolated decision making by national policy makers. In view of prior research at the organizational level, we also expected exchanges to continue to be marked in their performance by the initial external conditions prevailing at the time of adoption (Lounsbury \& Ventresca, 2002; Stinchcombe, 1965). Below, we derive hypotheses from each of four mechanisms of global diffusion identified by Simmons et al. (2006): coercion, competition, learning, and emulation. We hypothesize first the antecedents to exchange adoption and then the expected effect of these initial conditions on subsequent exchange performance. As we noted previously, although motivations and skills existing at the time of adoption may be impossible to measure directly, observation of subsequent success can serve as indicators about a key claim of neoinstitutional theory: whether symbolic or perfunctory adoption is likely to lead to weak implementation, as market success cannot be mandated; and whether "sincere" adoption is more likely to be followed by strong implementation.

Coercion. Coercion occurs when dependent states adopt practices because of pressures emanating from the center of the global economy (the "global core") and its agencies (Chase-Dunn, Kawano, \& Brewer, 2000; Strang, 1990). With the ascent of a neoliberal approach to economic governance, the creation of local stock markets is in line with the belief system of powerful actors at the core of the global economic system. Company shares traded on an exchange can be bought and sold in a manner that is swift and inexpensive, compared to making foreign direct investments. This ease of investment is particularly attractive to the growing number of institutional investors in core countries, especially the United States, that need market infrastructures to access assets and "rents" in peripheral countries (Useem, 1996). Stock markets also promise to reduce the direct influence of local political elites over choice of investments, degree of control, and ease of exit.

A country's immediate financial dependency on international agencies and core countries provides the structural linkage for coercive power and is expected to increase the influence of the global elite over local policies. Financial aid and credits disbursed and administered by international development agencies such as the World Bank and the IMF are particularly potent in this regard (International Monetary Fund, 1997; McMichael, 1996). The World Bank and the IMF provide not only money but also economic policy advice and pro- gram assistance. They do so as instruments of core states and global elites who define the agencies' goals and policies and supply the resources necessary for their operation (Brune, Garrett, \& Kogut, 2004; Gowan, 1999). Lending at concessional rates plays a particular role in the transfer of policy agendas. Concessional aid involves loans that are disbursed at discounted interest rates but are tied to the implementation of specific development programs and policies stipulated by the IMF or World Bank, such as structural adjustment programs aimed at changing a country's financial and fiscal systems. The dependency on international agencies for aid has been shown to have a significant impact on the adoption of organizations and policies in line with the institutional paradigms of the global core (Henisz et al., 2005; Polillo \& Guillén, 2005).

Hypothesis 2a. The more financially dependent a country is on concessional aid from the

IMF and the World Bank, the more likely it is to create a stock exchange.

But it is also clear that practices resulting from coercive pressures are more likely to reflect ceremonial compliance because motivations, skills, and resources for making the practices thrive do not become distributed in a local setting (cf. Kostova \& Roth, 2002). Agencies such as the IMF cannot demand that a market grow big. The sustained vibrancy of exchanges requires more comprehensive institutional alignments that are beyond the scope of the policy interventions under the control of international policy makers. Notably, IMF programs are project-based, with a specified scope usually centered on legal and governmental action and with monitoring mechanisms limited to compliance with the formal conditions attached to episodic concessional lending (Vreeland, 2003). IMF programs may thus be successfully implemented, but continued growth of markets requires sustained changes in the beliefs and motivations of multiple market stakeholders. Just as corporations create weak equal employment offices to visibly signal compliance with coercive pressures (Edelman, 1992), so states dependent on aid may signal their compliance with the adoption of structures that are more symbolic than substantive and relatively decoupled from other elements of the countries' institutions. This scenario makes the creation of "perfunctory" exchanges more likely.

Hypothesis 2b. Stock exchanges adopted in the wake of IMF/World Bank aid are smaller than those adopted without such aid.

Competition. A second mechanism of diffusion is competition. Policy makers are driven in part by 
the actions of other states with which they compete in the global economy. Consider, for instance, the global garment industry: although Mauritius, Cambodia, and Honduras may share little in terms of language, history, and culture, policy makers are acutely aware that these countries are competitors when it comes to providing finished garments for the branded clothing industry, and each may attend to its competitive position relative to the others. (Cambodia, for instance, competes on the basis of its high level of compliance to labor standards.) Burt (1987) cast competition as (structural) equivalence in network terms: adopting the actions of those sharing similar relations with third parties. The underlying mechanism is one of seeking an edge in contests between rivals that could replace each other in performing a role (Mizruchi, 1993). In the case of economic infrastructure, competition is often over trade relationships. Thus, the most relevant competitors are those that trade with the same third parties. Prior research has supported this argument; for instance, Polillo and Guillén (2005) found that states were more likely to adopt central bank independence to the extent that trade competitors had previously done so. If the creation of an exchange makes a country a more attractive partner for trade and investment, then moves by states are likely to be followed by countermoves by their competitors.

Hypothesis 3a. The more a country's competitors in trade have adopted stock exchanges, the more likely the country is to create a stock exchange.

Policy adoption due to competition is more ambiguous in its effects than adoption through coercion. If practices and policies are simply designed to reflexively keep up with rival countries and to match their moves, their implementers may lack the insight and capabilities for effective implementation. And to the extent that rivals refrain from sharing knowledge, insights from competitors' adoptions may be limited to easily observable features. Adoption may be mostly symbolic, and the resulting exchanges are likely to be relatively small. On the other hand, if adoption is central to ongoing competitive rivalry and rival countries are effective in their implementation, the ongoing monitoring of competitors and rivalry can be expected to pull a focal country toward enlarging its exchange as a more sustained activity. Given this ambivalent treatment of competitive mimicry in institutional theory, we alternatively hypothesize:

Hypothesis 3b. Stock exchanges adopted through mimicry of competitors are smaller than those adopted for other motivations.
Hypothesis 3c. Stock exchanges adopted through mimicry of competitors are bigger than those adopted for other motivations.

Learning. A third mechanism of diffusion is learning-that is, drawing on the experiences of others, particularly those seen to be successful pioneers and relevant peers. In contrast to competitiondriven adoption, which typically occurs through external observation, learning relies on proximity and direct channels of communication. Proximate others are more salient, more observable, and more trusted sources of information about appropriate conduct (Davis \& Greve, 1997; Greve, 1998). It should be noted that knowledge contagion and learning can occur from both the successful and unsuccessful experiences of others. As a result, ideas and policies are likely to diffuse through networks of proximate countries. The relevant measure of proximity is of course context specific. In the international economic policy sphere, shared regional identities and trade ties particularly heighten learning processes. Regional proximity subsumes several drivers of contagion, including the information effect of geographic proximity; similar historical and cultural experiences that increase the relevance and attention to communication of experiences; and routine policy consultations in regional intergovernmental treaty organizations. The adoption of stock exchanges by geographically proximate states can therefore be expected to increase a focal country's likelihood of adoption. Trade ties similarly are a conduit for the spread of information and practices (Henisz et al., 2005; Waters, 1995). ${ }^{1}$

\footnotetext{
${ }^{1}$ We note here that proximity is intended as an observable proxy for the degree of communication among policy makers in a country and its alters. It is impossible to observe the actual relevant communication among policy makers, but our expectation is that closer proximity (in geopolitical space or through trade) is associated with a greater volume of relevant communication. Note that Polillo and Guillén (2005) and Henisz et al. (2005) used trade ties to prior adopters as a proxy for normative rather than informational learning influence. However, their rationale was based on group cohesion leading to normative consensus pressures and consequently their measure used cumulative adoption by trade partners. In contrast, our interest is in the effect of recent adoption events among late adopters, so arguments at the aggregate level are less salient. Moreover, normative emulation is based on seeking credibility in the eyes of actors with normative authority, and it is unclear that such normative authority can be attributed to every trade partner. Hence, any interpretation of trade cohesion as only about emulation confounds normative influence with more ge-
} 
Hypothesis 4a. The more a country's regional neighbors and trade partners have adopted stock exchanges, the more likely the country is to create a stock exchange.

Exchanges adopted out of learning are likely to be those implemented most successfully. The motivation for adoption is based on interest in and engagement with the practice rather than externally induced compliance. Ongoing contact with prior adopters allows for ongoing vicarious learning and exchange of useful information. Moreover, countrylevel ties based on direct trade and regional proximity foster a multiplexity of ties between the various government, investor, business, and policy communities that are critical for effective implementation and exchange performance. Thus, to the extent that learning was the mechanism at play in proximity-based adoption, we expected successful and sustained implementation and performance.

Hypothesis $4 b$. Stock exchanges adopted in the wake of adoptions by regional neighbors and trade partners are larger than those adopted without such prior adoptions.

Emulation. A final explanation for the purposeful creation of new institutions in states is central to the world society perspective (Meyer et al., 1997). Just as organizations may adopt practices for ceremonial purposes rather than to meet technical requirements (Meyer \& Rowan, 1977), developing countries might adopt policies and corresponding organizations for reasons of global legitimacy. The technical functionality of policies is secondary in this perspective, and a symbolic function of emulating the prescriptions of high-status elites replaces it. The motivation for adoption is to appeal to the normative expectations of prominent external audiences, not to solve local problems, and knowledge is based more on general broad ideologies than on deep insight. A considerable number of studies have documented such processes in the global diffusion of policies, institutions, and organizations, from environmental protection (Frank, Hironaka, \& Schofer, 2000) and democracy (Wejnert, 2005) to policy orientations such as economic liberalism (Simmons \& Elkins, 2004) and the specific practices of deregulation (Henisz et al., 2005), intergovernmental investment treaties

neric information flows between countries. Following Waters (1995), we treat trade-based proximity more agnostically as facilitating interaction, information exchange, and learning, and we reserve emulation arguments for a country's connectedness to specific actors that more clearly possess normative authority.
(Elkins, Guzman, \& Simmons, 2006), and central bank independence (Polillo \& Guillén, 2005). To wit, countries may create exchanges because they are seen as generally appropriate by high-status evaluators that represent the membership of the "society of nations."

The transnational world stage around the issues of economic development is akin to an increasingly structured organizational field at the national level, and this increasing "structuration" gives rise to isomorphic processes (DiMaggio \& Powell, 1983). In the field of economic development policy, a nexus of actors develops fieldwide norms for institutional design and development policies with limited regard to local conditions. Development discourse shaped in dominant Western countries at the core of the global political economy serves as a template for how nations should manage their economies. Professional development consultants and economists in transnational "epistemic communities" frame the debate and rationalize institutional solutions (Fourcade-Gourinchas, 2001; Haas, 1992). Policy makers in developing countries are peripheral and less prestigious participants in this world community. Faced with the society of nations and global elites as arbiters of their conduct, they manage legitimacy by implementing templates theorized by global professional elites and used by high-status countries.

If more peripheral countries create financial markets in an effort to maintain legitimacy and gain prestige, two factors can be expected to explain uneven adoption through emulation on the part of more peripheral countries. First, a country's closeness to the core of the world economic system increases its visibility and hence global elites' scrutiny of its policies. Moreover, closeness to the core increases a country's desire to conform with core actors' institutional norms in an effort to attain the status of a member of the core. Greater integration into the core of the capitalist system, in terms of a country's position in international economic and political networks, has been shown to further the diffusion of other policies emanating from the core (Polillo \& Guillén, 2005; van Rossem, 1996; Wejnert, 2005). It is noteworthy that almost all capitalist countries conventionally designated as core, and many designated as semiperipheral, created exchanges well before the 1980s, so that the further spread of exchanges in the 1980s and 1990s amounts to an expansion of a core institution to more peripheral countries, with a parallel creation of more advanced financial institutions, such as options exchanges, at the core. The process of normative emulation among late adopters therefore resembles middle-status conformity processes (Phil- 
lips \& Zuckerman, 2001)-countries closer to the core and in the middle of the world system distribution face higher expectations to live up to their position and have stronger desires to associate with the core through symbolic actions.

A second fulcrum of normative exposure is the extent to which local participants in policy making are part of global professional networks. Professional epistemic communities play a key role in normative institutional pressures (DiMaggio \& Powell, 1983; Haas, 1992). For example, an epistemic community of U.S.-trained economists is often credited with having promoted economic liberalization in Latin America when they gained local footholds (Murillo, 2002; Simmons et al., 2006). Variation in countries' policy adoption results from varying exposure of countries to these professionals and from varying structural access of global professionals to local policy makers.

\section{Hypothesis 5a. Given controls for other inter-} nal, coercive, and mimetic factors, countries are more likely to create stock exchanges to the extent that they are subject to normative pressures through greater centrality in the world economic system and ties to the global financial community.

Institutional research portrays adoption out of emulation as prone to being decoupled from implementation for several reasons. First, the legitimacy benefits of adoption are likely to accrue to states regardless of the vigor of their subsequent implementation (cf. Westphal \& Zajac, 1998). Second, the practices developed by high-status actors may not be workable or functional for emulators that occupy a different structural position. They may lack the requisite skill to move beyond ritualistic emulation because knowledge, for example, is based on generic ideologies rather than fine-grained insight. "Whereas conventional logic-of-development arguments suggest that countries will adopt certain programs when they are developmentally ready for them, world polity theorists have found that countries embrace new norms for symbolic reasons even when they cannot begin to put them into practice.... Even in the realm of economic policy, countries may adopt new global norms before they are really ready" (Simmons et al., 2006: 800-801). The policy makers proximate to prior adopters are likely to have continued direct communication relevant to locally successful implementation, yet those that adopt out of emulation of high-status others are more prone to adoption without knowledge relevant to their local setting and with a primary motivation of symbolic legitimacy.
Hypothesis 5b. Given controls for geographic and trade proximity to prior adopters, stock exchanges adopted by more central countries and those tied into the epistemic financial community are smaller than those adopted by other countries.

Although it may seem counterintuitive that the exchanges of more central countries are smaller, it is important to emphasize that the population contemplated here is only those nations that did not have exchanges prior to 1980. Obviously, core economies, such as members of the Organisation for Economic Cooperation and Development (OECD), and some countries on the semiperiphery, had already created exchanges by then. Our argument is that exchanges will be smaller among those countries that are more central is relative to other late adopters, who according to neoinstitutional theory are particularly prone to legitimacy-based adoption of practices (Tolbert \& Zucker, 1983).

\section{METHODS}

\section{Population and Sample}

The "at risk" population of our study was any country that existed in 1980 or subsequently and did not have a stock exchange as of 1980. We excluded Communist countries in the Soviet bloc from the risk set prior to 1989. The list of countries was compiled from the United Nations (UN) directory of countries and the U.S. Central Intelligence Agency (CIA) World Factbook. By 1980, 59 countries had established one or more exchanges, which excluded these countries from the risk set. Additional countries entered the risk set when they became formally independent and exited the risk set when they were dissolved or created exchanges. Excluding exchanges created prior to 1980 raised issues of "left censoring." However, restricting the study period was justified for theoretical and empirical reasons. It was only with the shift to economic liberalism the early 1980s that stock markets came to play the role for economic policy that is at the heart of our arguments. Not surprisingly then, the 1980 s and 1990s capture a rapid increase in adoption events (see Figure 1). Only 14 exchanges were created in the 20 years from 1960 to 1980, despite the fact that numerous countries gained independence during this period. By contrast, 54 countries opened exchanges in the 20 years from 1980 to 2000 , nearly doubling the number of countries with exchanges. The period from 1980 to 2005 therefore captures the phenomenon of theoretical interest: temporal processes of global policy diffu- 
sion. To assess whether our results were affected by left censoring, we also tested a two-stage selection model (Heckman, 1979). The first-stage model estimated the chance that a country already had an exchange in $1980,{ }^{2}$ and we then inserted the inverse Mills ratio from this model as a control into the adoption model. The control variable itself was not statistically significant, and all substantive effects remained unchanged.

\section{Dependent Variables}

Stock market creation. Our first dependent variable was the time of establishment of a country's first stock exchange. We ignored the subsequent creation of additional exchanges as well as the existence of commodity exchanges. ${ }^{3}$ If an exchange existed on a country's territory prior to independence, the country was excluded from the risk set. The date of establishment of an exchange was the first trading day reported in the Handbook of World Stock Derivatives and Commodity Exchanges. We checked entries in this book for each year of its publication and cross-referenced exchange web pages and regional associations to verify complete coverage and to obtain the exact dates. This was done because founding events are sometimes reported only with some delay in the Handbook and because new exchanges could potentially close or merge shortly after their founding. None of the exchanges in our sample closed or was moved as part of regional consolidation. The Appendix describes this variable and all our other variables in greater detail.

Stock market vibrancy. Our second set of dependent variables addressed the vibrancy of the stock markets created between 1980 and 2005 . These data came from the 2007 World Development Indicator (WDI), a compilation of information from various sources published by the World Bank. We measured the number of domestic companies listed on an exchange and their combined market capitalization as a percentage of country GDP. Market capitalization was the share price of all listed firms times the number of their shares outstanding. The two measures captured different aspects of

\footnotetext{
${ }^{2}$ We included population, GDP per capita, years since independence, and dummy variables for world system position (van Rossem, 1996) and region (UN classification) in this estimation. The pseudo- $R^{2}$ of this selection equation was .63.

${ }^{3}$ In almost every case, the first stock exchange remained the only one during the study period. The most notable exceptions are Ukraine (with 5 exchanges, one of which accounts for 95 percent of turnover) and Russia, with 60 registered stock exchanges.
}

market performance. The number of traded companies indicated the attractiveness of listing shares on the exchange for companies as well as the investment choices available to investors. If the goal of market creation is to stimulate indigenous entrepreneurship and promote market governance of economic assets, then the number of companies listing on an exchange is an apt indicator of vibrancy. ${ }^{4}$ Market capitalization, on the other hand, captures what overall portion of a country's economy is governed by financial markets. A country can have many small companies listed on an exchange while large sectors of the economy remain closely held or under state control. If the intention of the market is to link the real economy to the world's financial system, then market capitalization relative to GDP is a good measure of vibrancy, and it is the most commonly used metric in the studies following LaPorta et al. (La Porta \& Lopez-de-Silanes, 1998; La Porta et al., 1999a). ${ }^{5}$

\section{Independent Variables}

National institutional endowment. We used several indicators of the compatibility of historical domestic institutions with stock exchanges: the percentage of a country's population of Protestant religionists in 1980 (La Porta et al., 1999b), a dummy variable for countries that were French colonies or protectorates prior to independence (coded from the World Factbook), a country's level of political democracy, and whether the ideology of a country's government was left-leaning (data for both the latter were from the Polity IV database). We also tested an opposite coding for British colonial history, and a coding for the origin of a country's legal system

\footnotetext{
${ }^{4}$ Factors other than institutional processes affect the supply of companies that could potentially list on an exchange, most prominently their country's size and stage of economic development. In the reported models, we control for country size and economic and financial development, effectively scaling the variable by these variables. As a robustness check, we also replicated the reported models with a dependent variable of the number of companies listed normalized by a country's GDP and omitting the GDP/capita control. This specification yielded consistent results.

5 Trading volume, another potential indicator of vibrancy, was not reported consistently enough by the exchanges in our sample and could not be used as an outcome measure. Foreign portfolio investments in equities, which could be construed as a less immediate indicator of an exchange's success in attracting foreign capital, was also not reported consistently enough for countries in this sample.
} 
(British common law or French civil law; see La Porta et al. [1998]). As expected, countries that were former British colonies consistently showed a pattern opposite to that of former French colonies. Legal traditions followed a similar pattern but produced weaker effects. Colonial history and legal tradition were so highly correlated that we could not include both in our analysis at the same time.

Dependence on international aid. We measured aid dependency as the concessional aid a country had received from the IMF and World Bank divided by the country's GDP (source: WDI database). Concessional aid is disbursed at a discounted interest rate but is tied to the implementation of specific development programs and policies stipulated by the IMF or World Bank. We treated concessional aid as a proximate channel of influence for global policy making communities located in international financial institutions. As concessional aid is mainly available to poor and highly indebted countries, we did, however, also explore whether the factors that qualify a country to receive this form of aid fully explain the creation and performance of stock markets, net of receiving aid. We implemented a selection model for receiving aid that included economic development, balance of payments, credit, and regional variables and entered the selection term in the main diffusion and performance models. ${ }^{6}$ The selection term was marginally significant, but the coefficient and significance of the aid variable remained unchanged relative to the models reported. This result supported our view that the actual receipt of aid constitute a specific channel of influence for international policy diffusion beyond the general economic conditions of countries.

Intercountry competition. We measured the degree to which countries were influenced by their competitors' adoption behavior using countries' positions in the international trade network. We measured intercountry competition on the basis of a country pair's similarities in patterns of trade. Conceptually, the variable reflected competition owing to countries' structural equivalence in the world trade system and was calculated as the normalized correlation between the import and export shares of two countries across trade partners, as used by Lee and Strang (2006). Intercountry com-

\footnotetext{
${ }^{6}$ We included population, GDP/capita, financial reserves in months of exports, total debt/GDP, total domestic credit/GDP, trade/GDP, and dummies for world system position (van Rossem, 1996) and region (UN regions) in the selection equation. The pseudo- $R^{2}$ of the selection equation was .52.
}

petition served as the weight for the influence that a prior adoption event in the other country exerted on a focal country. Annual trade data came from the United Nations COMTRADE database. We updated the measure of trade competition every five years and updated prior adoption events annually, thus obtaining an annually updated variable.

Our measure of competition differs from others, developed by Guler, Guillén, and Macpherson (2002) and Polillo and Guillén (2005), that are based on the concept of role equivalence, in that we used trade data at the country aggregate level instead of the product category level. (For a general discussion of structural versus role equivalence see, e.g., Mizruchi [1993].) Guler et al. (2002) suggested that their measure provides a more precise approximation of intercountry competition than do structural equivalence measures, because it combines information about product categories and the direction of trade, while structural equivalence measures only take into account competition for access to aggregate country-level markets. The trade-off is that reliable product-level reporting of trade is relatively uncommon for many low-income countries, especially during the early years included in our study. Although our measure is therefore coarser-grained, it allowed us to include a larger number of the many less developed countries in our risk set.

Intercountry learning. We measured two sources of contagion processes that map onto different dimensions of proximity among countries. The first measure is the number of recent adoption events in a country's region; regions were as defined by the World Bank. These regional groupings are widely used in reporting and analyses in the international economic policy community and approximate regional reference groups and data reporting as well as geographic proximity. We focused on recent adopters because recent events have been shown to be most salient and relevant in diffusion processes (Strang \& Tuma, 1993). ${ }^{7}$ We controlled for the cumulative percentage of prior adopters in a region

\footnotetext{
${ }^{7}$ We used a count of regional adoption events in past years in the reported analyses, performing several robustness checks on this specification. We tested alternative variables with 3-, 5-, 10-, and 15-year windows. Using the 3 - and 5-year windows yielded the same pattern of results as reported here. The direction of the coefficient remained consistent, but its statistical significance dropped for the 10- and 15-year windows. We also tested 3-, 5-, 10-, and 15-year window variables in which the weight of adoption events exponentially decreased with time. All four of these "time fade" variables yielded results highly consistent with the variable reported here,
} 
and the total size of the regional risk set. The second measure used proximity in trade networks to weigh adoption events. Following the "cohesion in trade" measure developed by Guillén and colleagues (Guler et al., 2002; Polillo \& Guillén, 2005: 1784), we captured intercountry learning processes by using bilateral trade data to measure the ratio of imports and exports from the influencing country to all imports and exports received by the influenced country annually. Annual trade data were from COMTRADE. Our measure weighted previous adoptions of a stock exchange by trade ties with adopters.

Normative emulation. We tested three indicators of normative world society mechanisms. First, we created a binary variable for a country being home to the headquarters of one or more international professional financial associations, which are associations of public and private finance professionals and organizations, as listed in the Yearbook of International Associations. Headquarters located in one of the generally more peripheral countries in the risk set suggested that this country had greater exposure to international financial expert communities and their normative discourse. We treated international professional financial associations as providing proximate channels of influence, similarly to how we treated concessional aid. A host country's economic and financial development and the global spread of development finance as a field are likely to influence the local presence of an international financial organization, and hence that presence cannot be treated as fully exogenous. We therefore interpret our findings for this variable strictly in terms of a proximate diffusion mechanism rather than as a broad causal factor. Second, we used a country's overall position in the world system in 1993, as reported by van Rossem (1996). Van Rossem used a block-modeling approach to collapse five types of intercountry ties (imports, exports, diplomatic, arms trade, troops) into four categories: core, semiperiphery, periphery 1 , and periphery 2 . We used core as the base category and collapsed both periphery clusters into one because many periphery 2 members were dependent territories that were excluded from our analysis. Although world system position is likely to change slowly, and 1993 fell in the middle of our sampling period, we also created an annual variable for a country's position. We focused on the global trade network as the most relevant tie for economic policy and calculated a country's "close-

supporting the importance attached to recent events in the diffusion literature. ness centrality" in the world trade system from annual input-output matrices of imports and exports. Closeness centrality reflects an established pattern whereby countries closer to the core are connected more directly to more others. Following van Rossem (1996: 512), we counted bilateral trade as a tie if either exports to or imports from the other country amounted to at least 1 percent of a focal country's GDP. We used annually standardized centrality measures to control for changes in the number of countries participating in global trade.

\section{Control Variables}

We controlled for the absolute size of a country with the natural logarithm of its population. We also controlled for gross national product (GNP) per capita (at current international prices) as a measure of a country's wealth and availability of capital. We used the natural logarithm of GNP per capita. We used GDP growth to control for economic dynamism. Several measures of a country's prior financial development, balance of payments position, and economic openness were also included. The natural logarithm of domestic credit over GDP was our proxy for financial development. Capital account balance scaled by GDP can be seen as indicative of a country's role in international capital flows, and total trade over GDP (logged) captures how integrated a country is in the global economy. We also included dummy variables for former Soviet countries and a time dummy for the 1990s to control for potentially unique dynamics in these countries and this time period. ${ }^{8}$ In the models for exchange vibrancy, we additionally controlled for liberalization of access for foreign investors, using the data on the "official equity market liberalization date" collected by Bekaert et al. (2005).

\section{Analyses}

We used semiparametric Cox proportional hazards models with robust standard errors to estimate

\footnotetext{
${ }^{8}$ We performed robustness checks for alternative controls: urbanization as a proxy for industrial development, bank lending as an alternative proxy for financial development, gross capital formation as a proxy for development progress, inward FDI as a proxy for economic openness, and status as an "offshore financial center" as designated by the IMF (www.imf.org/external/np/ofca/ ofca.asp) or the BIS (www.fsforum.org/publications/ r_0004b.htm). The coefficient pattern and significance of all substantive variables remained consistent with any one of those variables. To maximize degrees of freedom, we did not include these potential controls in the estimations shown in this study.
} 
countries" "transition rates"-that is, the rates at which they moved from nonadopter to adopter. The unit of observation was the country-year. Time to adoption was measured from January 1, 1980 (the beginning of our sample period), or from the point at which a country first became independent, if this was after 1980. We replicated the analyses reported here using Cox models with two alternative specifications for correlated errors withincountry: clustering by country and shared frailty models. All substantive results were robust across these specifications.

We used population-averaged generalized estimating equations (GEE; Zeger \& Liang, 1986) with robust standard errors to predict exchange vibrancy and specified all models with AR(1) temporal autocorrelation. We specified a logarithmic link function (family negative binomial) for the number of companies listed on an exchange and replicated this analysis using a measure that normalized the number of companies by country GDP. We specified a logarithmic link function (family Gaussian) for market capitalization. We measured global institutional variables at the time an exchange was created to account for conditions at the time of adoption. We measured nation-level control variables concurrently to account for changing national conditions for exchange vibrancy. The number of observations for our analyses of vibrancy was limited to the 58 adopters. These analyses allowed inferences only about the vibrancy of exchanges created between 1980 and 2005 and did not speak to broader economic performance differences between adopters and nonadopters.

One methodological challenge in international diffusion research, known as "Galton's problem," is to distinguish true cross-national influence caused by interdependence between countries from common exogenous shocks or correlated country-level factors. Inadequate modeling of simultaneous interdependence tends to misestimate the relative importance of common shocks and between-country processes (Anselin, 2006; Franzese \& Hays, 2007, 2008). This is a matter of both relative measurement and proper specification of spatial autocorrelation. To address the common problem of underestimating interdependence, Franzese and Hays $(2007,2008)$ proposed the use of spatial autoregressive (SAR) models based on specifying a proximity matrix $W(N \times N$ countries in our case) on theoretical grounds and taking into account systematic and stochastic spatial components. We present SAR models that replicate the analyses for exchange performance using the Franzese and Hays approach in addition to the GEE implementation. We note that our data structure is more complex than the basic SAR case. Our data contain multiple spatial dimensions (region, trade cohesion, trade competition), and the two trade-based measures of proximity are also time-varying. Although the general SAR approach has very recently been generalized to this data structure in the form of multiparametric spatiotemporal autoregressive (m-STAR) models (Franzese, Hays, \& Kachi, 2008), the reliability of this approach has not been evaluated. Spatial lag models may also generalize, but to our knowledge they have not been tested for hazard rate models (Franzese, 2008 personal communication), which would be desirable for reporting fully parallel analyses of adoption and performance as suggested by our hypotheses. In light of these issues, we present separate spatial lag models of exchange performance as a validation for the main analysis, estimating separate models for each spatial dimension. We used time-varying proximity matrices for the two trade variables. The spatial autocorrelation parameter in these models represents ongoing intercountry influence at time $t$, and the coefficients of the context conditions at the time of exchange creation can be interpreted as the effect of founding conditions at $t_{0}$. In an exploratory m-STAR replication of these analyses, we found that the three spatial dimensions were consistently jointly significant and the main substantive findings were confirmed. However, the magnitude of each dimension's spatial lag coefficient varied across specifications, and maximum-likelihood estimates for exchange liberalization could not be obtained without the omission of some variables. This result points to limitations in our data (sample size, correlation among spatial dimensions) that are such that SAR models cannot well attribute concurrent interdependence to the dimensions of region, trade cohesion, and trade competition (Franzese \& Hays, 2008: 40). Hence, we present single-parameter SAR models as robustness checks.

\section{RESULTS}

Table 2 reports pooled summary descriptive statistics and correlations for countries in the risk set. As Table 2 shows, correlations are generally low to moderate. Table 3 shows estimates of adoption models. We report models for only control variables; variables corresponding to each hypothesis; and combined models with all predictors included. The estimates shown are based on a consistent sample of 75 at-risk countries for which data on all included variables were available. We replicated this analysis with varying numbers of countries depending on data availability (75-113 countries, 869-1916 country-years). These analyses con- 


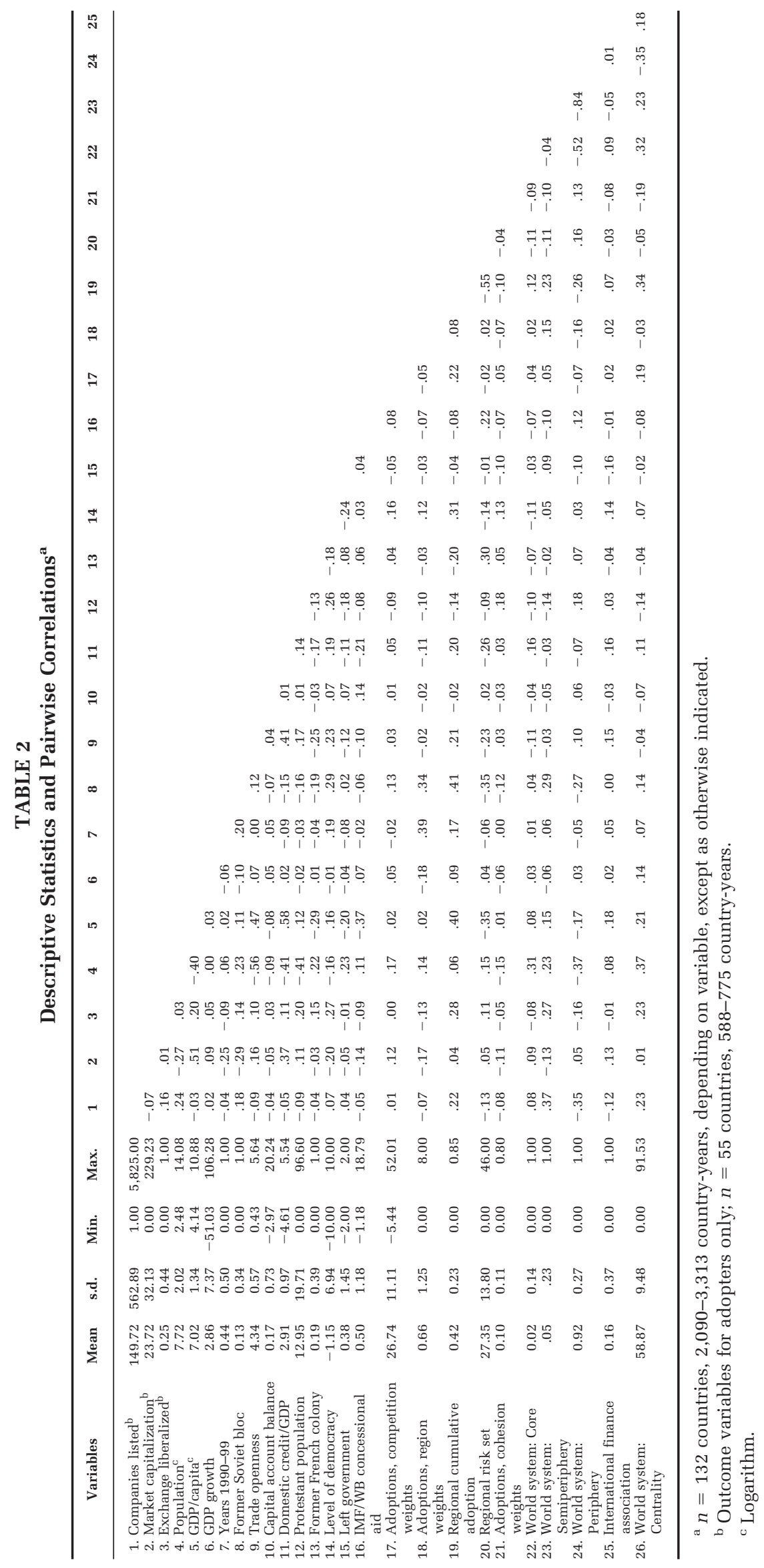




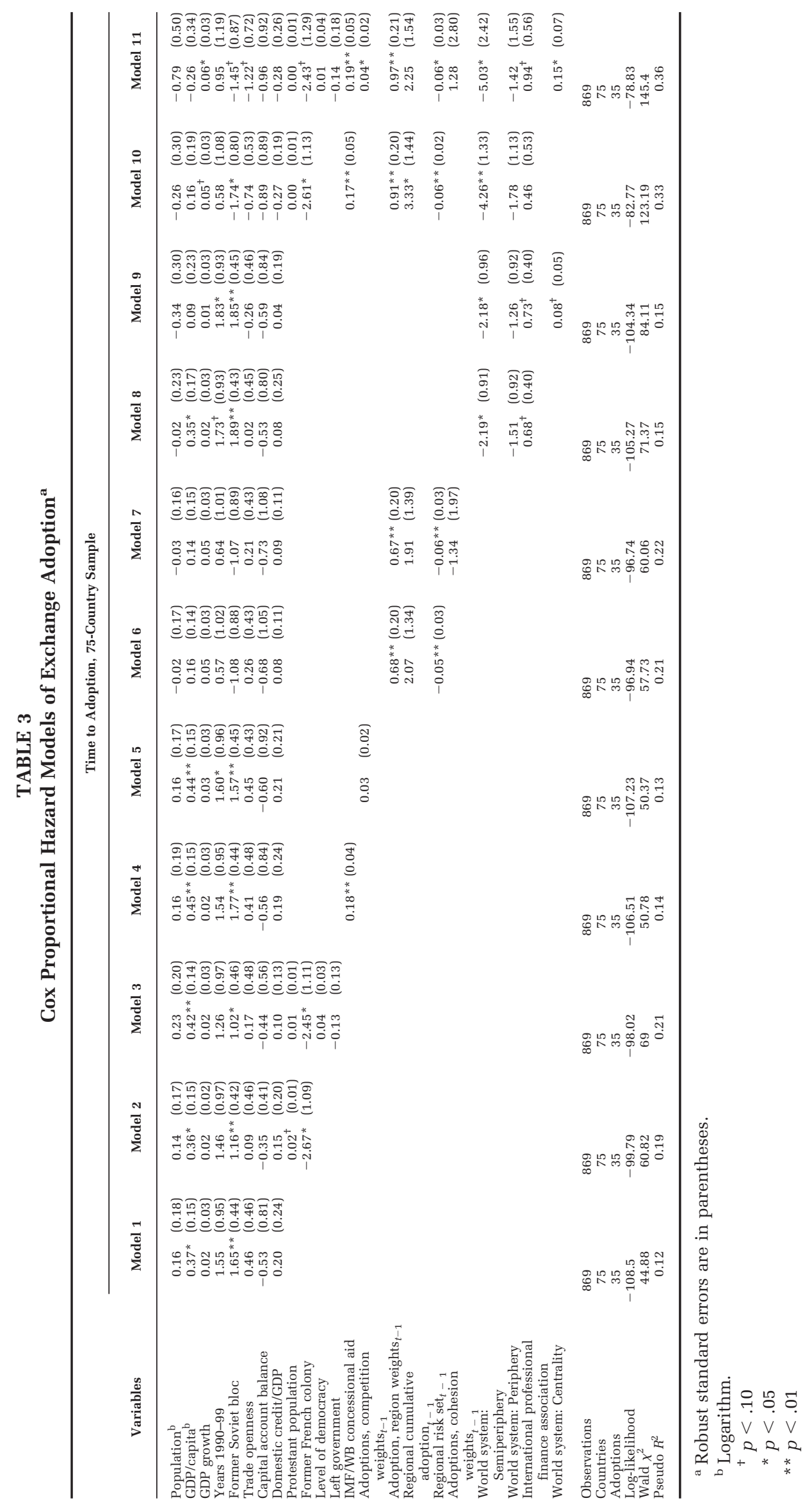


firmed the results shown in Table 3 and suggested that the findings were robust for different country sets. Table 4 shows the results of analyses of the vibrancy of the exchange for the different modeling frameworks. Panel 4a shows models for the number of companies listed on an exchange, and panel $4 \mathrm{~b}$ shows models for market capitalization. We again show models for a set of 52 adopting countries for which most variables were available and for 34 countries for which we could obtain data for all variables. Panel 4c shows an additional analysis of equity market liberalization (that is, granting foreigners unrestricted access to a market [Bekaert et al., 2005]). Only 4 of the 56 exchanges were formally liberalized from their inception (Lebanon, Namibia, Poland, and Romania), so that their subsequent opening to foreign investors can be seen as a proxy for the extent of implementation-full implementation of the neoliberal economic policy logic behind the global diffusion of exchanges in the study period. Model 4c was specified as a GEE with a probit link function (family binary) with AR(1) temporal autocorrelation. We used LeSage's (1999) Baysean probit to implement the probit analysis in a spatial autocorrelation framework.

Table 3 shows that a French colonial legacy reduces the likelihood that a country creates an exchange, and Table 4 suggests that exchanges created by these countries tend to have fewer listed companies. We found no link between the level of Protestantism, the level of democracy, or the ideology of a country's rulers and the propensity to create an exchange. We did, however, find a tentative negative association between Protestant religion and number of companies listed, and conversely there were indications of a positive relationship between Protestantism and subsequent market size. The pattern of results for colonial legacy and to a lesser extent for Protestantism are consistent with Hypotheses 1a and $1 \mathrm{~b}$, stating that a country's prior institutional legacy influences both its likelihood of creating an exchange and the exchange's performance. In robustness checks not reported here, we found a mirror pattern for exchanges created by former British colonies, as expected in view of prior research on historical institutions. Note that even a more complete implementation of a neoliberal policy through formal market liberalization does not eradicate this effect of common history.

Hypotheses 2a and 2b led us to expect that coercive policy diffusion, in the form of dependence on concessional IMF and World Bank aid, would be positively associated with the creation of an exchange but negatively associated with the exchange's vibrancy. Table 3 confirms Hypothesis 2a, showing a robust, positive effect of aid on adoption.
Panel 4a shows support for Hypothesis 2b, especially once spatial autocorrelation is taken into account. The negative effect on the number of companies listed is consistent over all statistically significant specifications. The receipt of concessional aid at the time of exchange creation also reduces market capitalization once spatial autocorrelation is modeled, at least in the smaller sample of countries with complete data (panel 4b, models $6,9,12) .{ }^{9}$ It does not affect liberalization, which may indicate that the coercive influence of international agencies is limited to the adoption of a specific formal program. Overall, this pattern shows good support for predictions associated with coercive mechanisms of diffusion.

Hypothesis 3a, relating to competitive diffusion mechanisms, is supported: the creation of exchanges by role-equivalent others increases the chance of adoption (Table 3). Hypotheses 3b and 3c present alternative rationales that link competitive diffusion to vibrancy. We found a marginally positive effect of trade competition at the point of founding on market capitalization in the SAR implementation (panel 4b, models 6, 9, 12) and observed a more consistent effect of autocorrelation based on contemporary trade competition in the models of market capitalization and liberalization. This pattern suggests that competitive adoption fosters policy implementation more through continued rivalry than through the initial imprinting process.

Table 3 shows that regional contagion processes promote the creation of exchanges, but trade ties do not. Table 4 further suggests that adoption influenced by regional contagion or the behavior of trade partners at the outset increases the chance of more complete implementation of the policy logic (liberalization) and is associated with higher market capitalization and more listed companies in subsequent years. In addition, the significant autocorrelation parameter in all models using regional or trade-cohesion-based proximity weights supports the notion of ongoing influence between countries tied through either dimension. This pattern lends general support to the learning view of peer diffusion articulated in Hypotheses $4 \mathrm{a}$ and $4 \mathrm{~b}$. Contagion through regional and trade ties may facilitate substantive implementation of the innovation, counter to much of the received wisdom in neoinstitutional theory. The strong spatial autocorrelation effects suggest that this is a result of focal

\footnotetext{
${ }^{9}$ In additional exploratory analyses, we also found concessional aid to reduce subsequent foreign portfolio investment flows. These analyses are available from the authors upon request.
} 


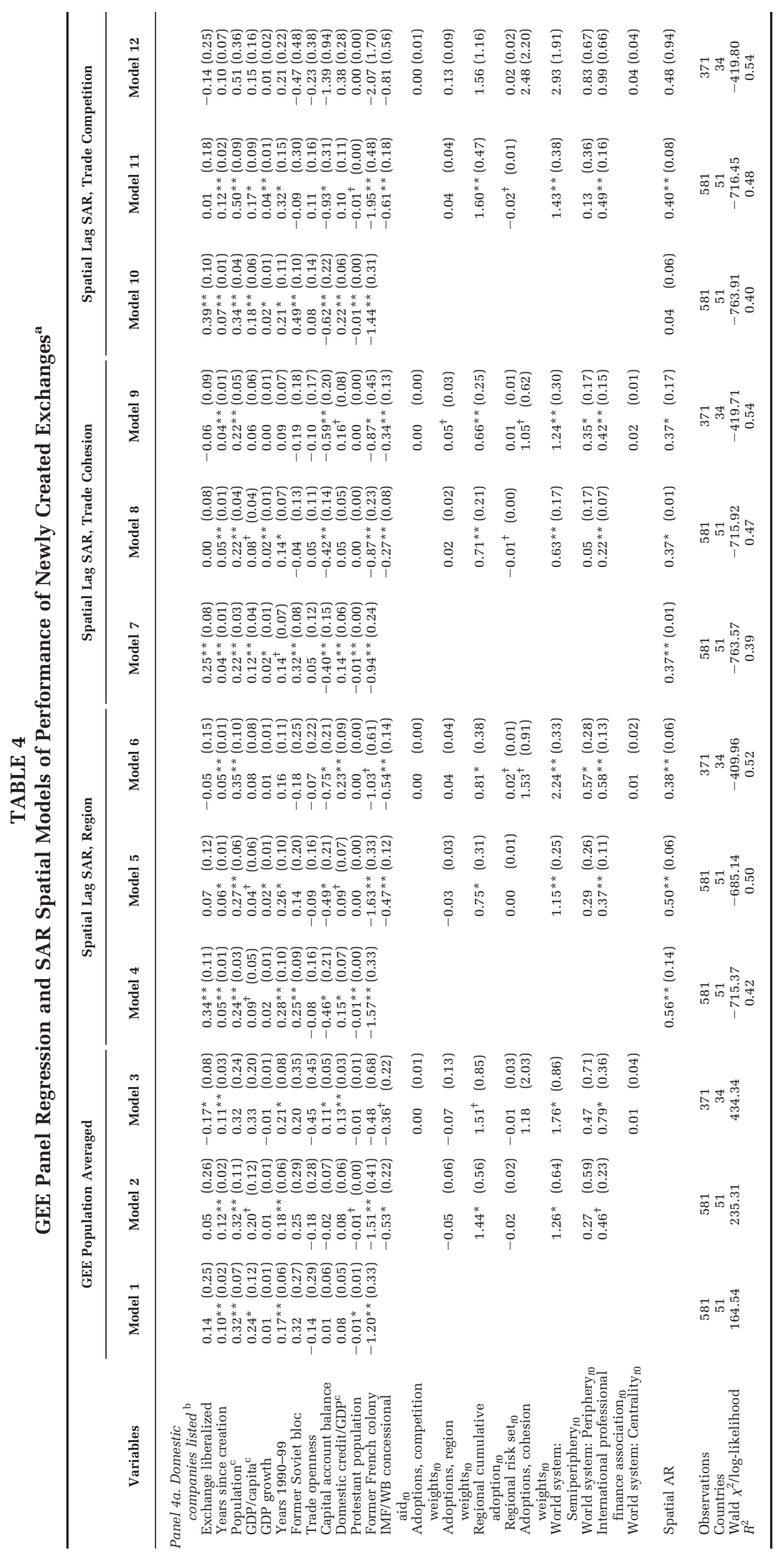




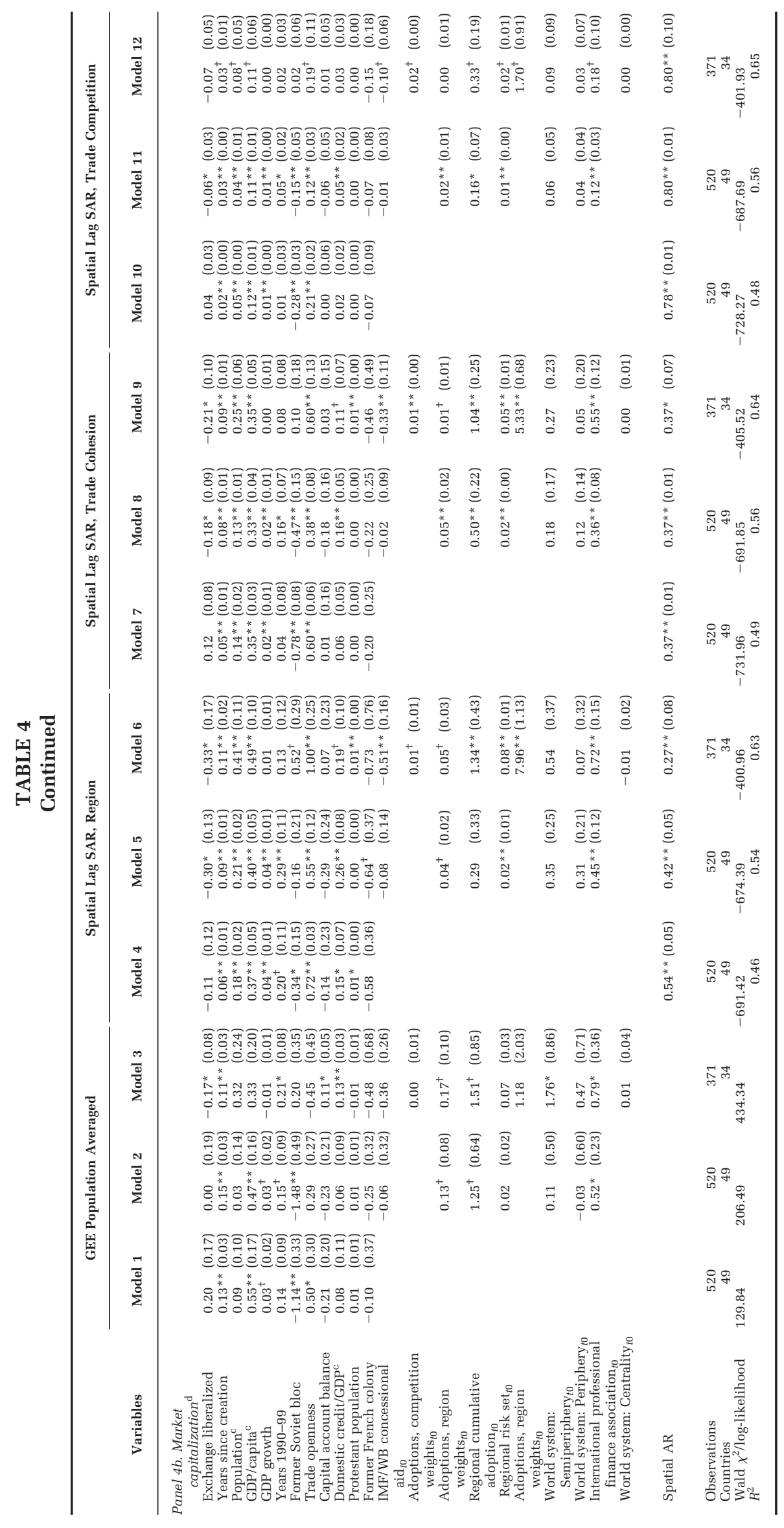




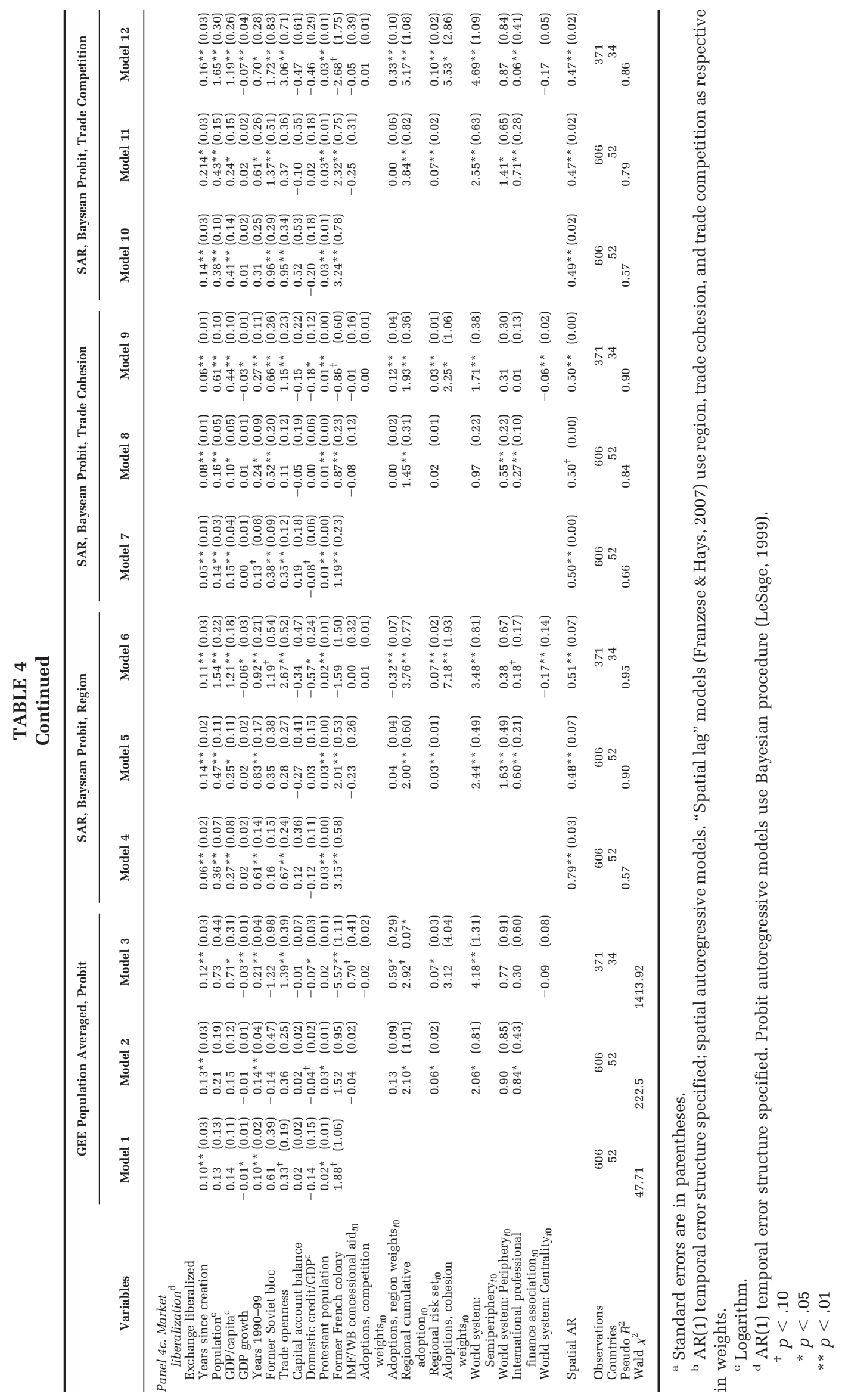


adopters continuing to learn from nearby adopters as much as of imprinting at founding (Davis \& Greve, 1997; Greve, 1998). Proximate adopters may also enhance the performance of a focal country via investment spillovers (Henderson \& Cockburn, 1996). ${ }^{10}$

Hypotheses $5 \mathrm{a}$ and $5 \mathrm{~b}$ predict that normative and status-based emulation processes, as a result of world system position and exposure to professional communities, prompt policy adoption but hinder subsequent vibrancy. We found support for Hypothesis 5a: countries with international professional finance associations and more central positions in the world trade network were more likely to create stock markets. However, contrary to Hypothesis $5 \mathrm{~b}$, adoption influenced by the presence of finance associations is positively associated with the number of companies listed, market capitalization, and market liberalization, all of which associations suggest that exposure to global professional communities enhances policy implementation. It appears that professional communities not only play the normative function so clearly emphasized in the neoinstitutional literature (DiMaggio \& Powell, 1983; Simmons et al., 2006), but also, in the international realm, provide non-state-based channels for ongoing diffusion of practical knowledge about institutions that conform to their ideology.

Semiperipheral countries are less likely to create exchanges (compared to the baseline category of those at the core), but when they do, they tend to have larger numbers of listed companies and to be more likely to liberalize their exchanges. Peripheral countries that adopt exchanges show a similar effect. More generally, normative emulation by coun-

\footnotetext{
${ }^{10}$ From our high-level data, we cannot conclusively attribute regional and trade contagion to learning mechanisms. The rationale for attributing learning processes to regional and trade cohesion is mainly based on the existing literature reviewed above. A narrower test would be to examine whether learning-based imitation takes into account the performance of the observed practice. The limitation for this approach in our sample of late adopters is that the policy itself is already proven to be successful, so that the relevant dimension of learning is not so much the generic success of the practice but access to proximate and fine-grained information. In addition, learning can occur from the success or failure of others when it comes to implementation. Empirically, with our use of one-year time lags in our models, the performance of another country's exchange cannot be observed by an adopter at the time of a its own decision. We tested if perhaps a prior adopter's general economic performance (growth in GDP or GDP/capita) improved the adoption or performance models, but like Lee and Strang (2006), we found no simple effect.
}

tries more connected to the core global elite appears to go beyond purely ceremonial adoption and toward more complete conformity with high-status actors, because adoption is based on a deeper internalization of normative policy logics diffusing from the core. As a result, policy makers neither seek to decouple formal practices from contrasting internal beliefs nor lack the capability to implement them.

\section{DISCUSSION AND CONCLUSION}

Two questions motivated this study: First, what is the role of international institutional diffusion processes in the adoption of economic policies and the organizational infrastructures associated with them? And second, does institutionally triggered adoption make for bad policy? That is, does international diffusion generally lead to "merely ceremonial" adoption of a policy? Most international institutional research has thus far only studied adoption and paid little attention to questions of operational performance. We studied the creation and vibrancy of national stock markets since the 1980 s as a critical component of the organizational infrastructure for market-based approaches to economic policy.

The answer to the first question is that institutional processes at the global level did indeed play an important role in diffusing stock markets to countries at the periphery of the capitalist "world society" during this period. We found evidence for international coercive, competitive, learning, and emulation processes. The answer to the second question is perhaps more provocative. Only international development aid seemed to match the pattern expected for ceremonial adoption: IMF and World Bank aid was a conduit for the creation of stock markets and was associated with these markets being less vibrant. However, linkages to international finance experts and regional and trade-based contagion appeared to enhance the robustness of exchange implementation and performance. These findings have implications for international policy implementation and for institutional research.

\section{Implications for Policy Research}

This study addresses two pragmatic policy-related questions. The first is, Does it matter-are the statistical effects we found of sufficient magnitude to inform policy decisions? The second is, What is the practical implication; what advice, however tentative, would one give to those concerned with national and international economic development? In regard to the first question, it should be noted that our study was designed to draw inferences 
about the implementation effectiveness of formally adopted practices. Hence, we are reluctant to speculate about the counterfactual of whether, for example, countries that created more ceremonial exchanges would be worse or better off economically had they not created an exchange at all or pursued alternative paths toward financial development. We performed one exploratory analysis of the difference in foreign direct investment (FDI) inflows between adopters and nonadopters in our risk set but found no statistically significant difference net of the control variables included in this study. This is clearly an area for ongoing research (see, e.g., Filer et al., 1999; Levine \& Zervos, 1998).

As to the magnitude of differences within countries that created exchanges, a 1 percent of GDP increase in concessional aid increased the adoption rate by 21 percent (Table 3, panel 3a, model 11) and reduced the expected number of firms listed by about 4 per year over the following years (Table 4 , panel 4a, model 3). It is important to bear in mind, though, that only 18 countries received concessional aid amounting to more than 5 percent of GDP at any time (6 of which created an exchange in the aftermath). The substantive significance of this effect can also be understood in comparison to other predictors. The adoption rate of former French colonies was 92 percent lower, and each prior regional adoption event increased the adoption rate by 165 percent and subsequent market capitalization by 2 percent of GDP per year. The presence of an international professional financial association increased the adoption rate by 155 percent and the number of companies listed by 5 and subsequent market capitalization by 3 percent of GDP per year. We emphasize the relative sizes of these effects because of two caveats for a more literal interpretation: the size of each effect varies depending on the specification and countries included in our models, and the interpretation of coefficients in time series models of exchange vibrancy is less straightforward than is interpretation in standard regression models.

What can national policy makers do to enhance the effectiveness of formally adopted development policies? One implication of our findings is that it is difficult for countries to overcome historical path-dependent development paths, and the most promising path to development may lead through the selective adoption of policy innovations that fit an existing system (e.g., Biggart \& Guillén, 1999). A second implication is that in order to reap expected benefits, local policy makers should address informal as well as formal policy aspects, for example by supporting the development of internationally connected professional elites and by engaging in multilateral and regional initiatives. What can interna- tional policy makers do to build more effective institutional frameworks in countries away from the core of the global political economy? Our analyses suggest that (1) efforts should be directed at building indigenous expertise and linkages to pools of international expert communities, because normative acceptance and continued access to knowledge and resources after initial adoption are necessary for further development of markets and that (2) coercive mechanisms, such as program-contingent aid from international development agencies, may be more successful when these external policy interventions are "robust": where acceptance and implementation of the desired practice involves a broader set of actors domestically and within a country's peer group so that a self-sustaining dynamic is more likely. The successful adoption of specific practices, such as financial markets, requires supporting changes throughout a country's entire institutional matrix and its external web of relationships. It is because of these informal and distributed parts of policy processes, that programbased and externally monitored interventions by development agencies may lead to ceremonial rather than expansive implementation. It is informative in this regard to contrast our findings with those of Brune, Garrett, and Kogut (2004), who found that IMF concessional aid was associated with more extensive privatization programs in terms of volume and valuation. The difference between our largely negative findings and the study by Brune et al. suggests that the "Washington consensus" approach to financial development is limited by its focus on episodic formal state programs (privatization, exchange liberalization, exchange creation) and fails to effectively foster the development of informal and distributed institutions that involve the private sector (fewer companies listed, portion of economy governed by market). Building a robust institutional matrix requires the creation of less formal and diverse structural linkages, as well as attention from policy makers extending beyond concessional lending episodes.

\section{Implications for Neoinstitutional Research}

This study sheds light on how institutional mechanisms of diffusion relate to the subsequent performance of a formally adopted practice or policy. In crude neoinstitutional accounts, it has often been assumed that innovations adopted as a result of institutional pressures are only symbolic and hence automatically less substantive, yet recent research has begun more nuanced examinations of the conditions under which formally adopted practices remain solely ceremonial or are also substantively 
implemented (Lounsbury, 2001; Westphal \& Zajac, 2001; Zelner et al., 2009). This line of research has often pointed to postadoption factors, such as ongoing monitoring of compliance, changing interests of the adopters, and degree of structural inertia. Our study suggests that institutional mechanisms at the point of adoption may also influence subsequent vibrancy. We found that coercive institutional pressures that trigger adoption are associated with more ceremonial, poorly performing exchanges, while peer influence and normative emulation enable more vibrant exchange activity.

The pattern we observed at the country level is akin to imprinting at the time of founding for organizations (Stinchcombe, 1965). If new organizations are influenced by the social context of their founding, new national practices and policies are influenced by their world society context. Subsequent development is partly path-dependent. The specifics of institutional diffusion processes, far from being only about immediate legitimation, may be more relevant for longer-term and substantive outcomes than is often presumed. Our study is one of the first to examine and refine conventional expectations around institutional adoption in the global sphere. Our findings suggest that more "microinstitutional" studies of the process of international policy diffusion and the formal adoption of national policies and practices are needed to further disentangle various mechanism (see, e.g., Woods [2006] for a recent example). In combination with high-level studies such as ours, such research may enhance the practical relevance of neoinstitutional theory for international policy makers.

\section{REFERENCES}

Allison, G. 1971. Essence of decision: Explaining the Cuban missile crisis. Boston: Little, Brown.

Anselin, L. 2006. Spatial econometrics. In T. C. Mills \& K. Patterson (Eds.), Palgrave handbook of econometrics, volume 1-Econometric theory: 901-941. Basingstoke, U.K.: Palgrave Macmillan.

Armijo, L. E. 1999. Introduction and overview. In L. E. Armijo (Ed.), Financial globalization and democracy in emerging markets: 10-14. New York: St. Martin's.

Bekaert, G., Harvey, C. R., \& Lundblad, C. 2005. Does financial liberalization spur growth? Journal of Financial Economics, 77: 3-55.

Biggart, N. W., \& Guillén, M. F. 1999. Developing difference: Social organization and the rise of the auto industries of South Korea, Taiwan, Spain, and Argentina. American Sociological Review, 64: 722747.

Brune, N., Garrett, G., \& Kogut, B. 2004. The international monetary fund and the global spread of privatization. IMF Staff Papers, 51(2): 195-219.

Burt, R. S. 1987. Social contagion and innovation: Cohesion versus structural equivalence. American Journal of Sociology, 92: 1287-1335.

Chase-Dunn, C., Kawano, Y., \& Brewer, B. D. 2000. Trade globalization since 1795: Waves of integration in the world system. American Sociological Review, 65: 77-95.

Clayton, M. J., Jorgenson, B. N., \& Kavajecz, K. A. 2006. On the presence and market-structure of exchanges around the world. Journal of Financial Markets, 9: $27-48$.

Cyert, R. M., \& March, J. G. 1963. A behavioral theory of the firm. Englewood Cliffs, NJ: Prentice-Hall.

Davis, G. F., \& Greve, H. R. 1997. Corporate elite networks and governance changes in the 1980s. American Journal of Sociology, 103: 1-37.

DiMaggio, P. J., \& Powell, W. W. 1983. The iron cage revisited: Institutional isomorphism and collective rationality in organizational fields. American Sociological Review, 48: 147-160.

Dobbin, F. 1994. Forging industrial policy: The United States, Britain, and France in the railway age. London, U.K.: Cambridge University Press.

Edelman, L. B. 1992. Legal ambiguity and symbolic structures: Organizational mediation of civil rights law. American Journal of Sociology, 97: 1531-1576.

Elkins, Z., Guzman, A. T., \& Simmons, B. A. 2006. Competing for capital: The diffusion of bilateral investment treaties, 1960-2000. International Organization, 60: 811-846.

Filer, R. K., Hanousek, J., \& Campos, N. F. 1999. Do stock markets promote economic growth? Working paper no. 268, William Davidson Institute, University of Michigan Business School.

Fourcade-Gourinchas, M. 2001. Politics, institutional structures, and the rise of economics: A comparative study. Theory and Society, 30: 397-447.

Frank, D. J., Hironaka, A., \& Schofer, E. 2000. The nationstate and the natural environment over the twentieth century. American Sociological Review, 65: 96116.

Franzese, R. J., \& Hays, J. C. 2007. Spatial econometric models of cross-sectional interdependence in political science panel and time-series-cross-section data. Political Analysis, 15(2): 140-164.

Franzese, R. J., \& Hays, J. C. 2008. Interdependence in comparative politics: Substance, theory, empirics, substance. Comparative Political Studies, 41: 742780.

Franzese, R. J., Hays, J. C., \& Kachi, A. 2008. The m-star model as an approach to modeled, dynamic, endogenous interdependence in comparative $\&$ inter- 
national political economy. Working paper, SSRN, June 13.

Goetzmann, W. N., \& Jorion, P. 1999. Re-emerging markets. Journal of Financial and Quantitative Analysis, 34: 1-32.

Gowan, P. 1999. The global gamble: Washington's Faustian bid for world dominance. New York: Verso.

Greve, H. R. 1998. Managerial cognition and the mimetic adoption of market positions: What you see is what you do. Strategic Management Journal, 19: 967988.

Guler, I., Guillén, M. F., \& Macpherson, J. M. 2002. Global competition, institutions, and the diffusion of organizational practices: The international spread of ISO 9000 quality certificates. Administrative Science Quarterly, 47: 207-232.

Haas, P. 1992. Epistemic communities and international policy coordination. International Organization, 46: 1-35.

Heckman, J. J. 1979. Sample selection bias as a specification error. Econometrica, 47: 153-162.

Henderson, R. M., \& Cockburn, I. 1996. Scale, scope, and spillovers: The determinants of research productivity in drug discovery. RAND Journal of Economics, 27: $32-59$.

Henisz, W. J., Zelner, B. A., \& Guillén, M. F. 2005. The worldwide diffusion of market-oriented infrastructure reform, 1977-1999. American Sociological Review, 70: 871-897.

International Monetary Fund. 1997. The role of the IMF in governance issues: Guidance note. Washington, DC: International Monetary Fund.

Kostova, T., \& Roth, K. 2002. Adoption of an organizational practice by subsidiaries of multinational corporations: Institutional and relational effects. Academy of Management Journal, 45: 215-233.

La Porta, R., \& Lopez-de-Silanes, F. 1998. Capital markets and legal institutions. In S. J. Burki \& G. Perry (Eds.), Beyond the Washington consensus: Institutions matter: 73-92. Washington, DC: World Bank.

La Porta, R., Lopez-de-Silanes, F., Shleifer, A., \& Vishny, R. 1998. Law and finance. Journal of Political Economy, 106: 1113-1155.

La Porta, R., Lopez-de-Silanes, F., Shleifer, A., \& Vishny, R. 1999a. Investor protection and corporate evaluation. Working paper no. 7403, National Bureau of Economic Research.

La Porta, R., Lopez-de-Silanes, F., Shleifer, A., \& Vishny, R. 1999b. The quality of government. Journal of Law, Economics, and Organization, 14: 222-282.

La Porta, R., Lopez-de-Silanes, F., Shleifer, A., \& Vishny, R. 2000. Investor protection and corporate governance. Journal of Financial Economics, 58: 3-27.

Lee, C. K., \& Strang, D. 2006. The international diffusion of public-sector downsizing: Network emulation and theory-driven learning. International Organization, 60: 883-909.

LeSage, J. P. 1999. Spatial econometrics. http://rri.wvu. edu/WebBook/LeSage/spatial/spatial.html.

Levine, R. 1998. The legal environment, banks, and economic growth. Journal of Money, Credit, and Banking, 30: 596-613.

Levine, R., \& Zervos, S. 1998. Stock markets, banks, and economic growth. American Economic Review, 88: $537-554$.

Levitt, B., \& March, J. G. 1996. Organizational learning. In J. Hagan \& K. Cook (Eds.), Annual review of sociology, vol. 14: 319-340. Palo Alto, CA: Annual Reviews.

Levy, J. S. 1994. Learning and foreign policy: Sweeping a conceptual minefield. International Organization, 48: $279-312$.

Lindblom, C. E., \& Woodhouse, E. J. 1993. Policy making process (3rd ed.). Englewood Cliffs, NJ: PrenticeHall.

Lounsbury, M. 2001. Institutional sources of practice variation. Administrative Science Quarterly, 46: $29-56$.

Lounsbury, M., \& Ventresca, M. J. 2002. Social structure and organizations revisited. In M. Lounsbury \& M. J. Ventresca (Eds.), Research in the sociology of organizations, vol. 19: 3-36. Greenwich, CT: JAI Press.

Manzocchi, S. 1999. Capital flows to developing economies throughout the twentieth century. In L. E. Armijo (Ed.), Financial globalization and democracy in emerging markets: 51-73. New York: St. Martin's.

March, J. G., \& Simon, H. A. 1958. Organizations. New York: Wiley.

McMichael, P. 1996. Development and social change: $A$ global perspective. Thousand Oaks, CA: Pine Forge Press.

Meyer, J. W., \& Rowan, B. 1977. Institutional organizations: Formal structures as myth and ceremony. American Journal of Sociology, 83: 340-363.

Meyer, J. W., Boli, J., Thomas, G. M., \& Ramirez, F. O. 1997. World society and the nation state. American Journal of Sociology, 103: 144-181.

Mizruchi, M. S. 1993. Cohesion, equivalence, and similarity of behavior: A theoretical and empirical assessment. Social Networks, 15: 275-307.

Murillo, M. V. 2002. Political bias in policy convergence: Privatization choices in Latin America. World Politics, 54: 462-493.

North, D. C. 1990. Institutions, institutional change and economic performance. Cambridge, U.K.: Cambridge University Press.

Phillips, D., \& Zuckerman, E. W. 2001. Middle-status 
conformity: Theoretical restatements and empirical demonstration in two markets. American Journal of Sociology, 107: 379-429.

Polillo, S., \& Guillén, M. F. 2005. Globalization pressures and the state: The worldwide spread of central bank independence. American Journal of Sociology, 110: 1764-1802.

Simmons, B. A., \& Elkins, Z. 2004. The globalization of liberalization: Policy diffusion in the international political economy. American Political Science Review, 98: 171-189.

Simmons, B. A., Dobbin, F., \& Garrett, G. 2006. Introduction: The international diffusion of liberalism. International Organization, 60: 781-810.

Spicer, A. 2002. Revolutionary change and organizational form: The politics of investment fund organization in Russia, 1992-1997. In M. Lounsbury \& M. J. Ventresca (Eds.), Research in the sociology of organizations, vol. 19: 91-124. Greenwich, CT: JAI Press.

Stinchcombe, A. L. 1965. Social structure and organizations. In J. G. March (Ed.), Handbook of organizations: 142-193. Chicago: Rand McNally.

Strang, D. 1990. From dependency to sovereignty: An event history analysis of decolonization 1870-1987. American Sociological Review, 55: 846-860.

Strang, D., \& Tuma, N. B. 1993. Spatial and temporal heterogeneity in diffusion. American Journal of Sociology, 99: 614-639.

Sutton, R. I., \& Dobbin, F. 1996. The two faces of governance: Responses to legal uncertainty in U.S. firms, 1995-1985. American Sociological Review, 61: $794-811$.

Tolbert, P. S., \& Zucker, L. G. 1983. Institutional sources of change in the formal structure of organizations: The diffusion of civil service reform, 1880-1935. Administrative Science Quarterly, 28: 22-39.

Useem, M. 1996. Investor capitalism: How money managers are changing the face of corporate america. New York: Basic Books.

Van Agtmael, A. W. 1984. Emerging securities markets: Investment banking opportunities in the developing world. London: Euromoney Publications.

van Rossem, R. 1996. The world system paradigm as general theory of development: A cross-national test. American Sociological Review, 61: 508-527.

Vreeland, J. R. 2003. The IMF and economic development. Cambridge, U.K.: Cambridge University Press.

Waters, M. 1995. Globalization. New York: Routledge.

Weber, M. 1904/1958. The Protestant work ethic and the spirit of capitalism [T. Parsons, trans.]. New York: Scribner's.

Wejnert, B. 2005. Diffusion, development and democracy. American Sociological Review, 70: 53-81.

Westphal, J. D., Gulati, R., \& Shortell, S. M. 1997. Cus- tomization or conformity? An institutional and network perspective on the content and consequences of TQM adoption. Administrative Science Quarterly, 42: 366-394.

Westphal, J. D., \& Zajac, E. J. 1998. The symbolic management of stockholders: Corporate governance reforms and shareholder reactions. Administrative Science Quarterly, 43: 127-153.

Westphal, J. D., \& Zajac, E. J. 2001. Explaining institutional decoupling: The case of stock repurchase programs. Administrative Science Quarterly, 46: 202228.

Williamson, O. E. 1975. Markets and hierarchies: Analysis and antitrust implications. New York: Free Press.

Woods, N. 2006. The globalizers: The IMF, the World Bank, and their borrowers. Ithaca, NY: Cornell University Press.

World Bank. 1997. Private capital flows to developing countries: The road to financial integration. Oxford, U.K.: Oxford University Press.

Zbaracki, M. J. 1998. The rhetoric and reality of total quality management. Administrative Science Quarterly, 43: 602-636.

Zeger, S. L., \& Liang, K.-Y. 1986. Longitudinal data analysis for discrete and continuous outcomes. Biometrics, 42: 121-130.

Zelner, B. A., Henisz, W. J., \& Holburn, G. L. F. 2009. Contentious implementation and retrenchment in neoliberal policy reform: The global electric power industry, 1989-2001. Administrative Science Quarterly, 54: 379-412.

\section{$M$}

Klaus Weber (klausweber@northwestern.edu) is an assistant professor in management and organizations at the Kellogg School of Management at Northwestern University. He received his Ph.D. from the University of Michigan, Ann Arbor. His research uses cultural, institutional and sensemaking approaches to understand the intersection between social movements and the economy, globalization, and environmental sustainability.

Gerald F. Davis (gfdavis@umich.edu) is the Wilbur K. Pierpont Professor of Management and a professor of sociology at the University of Michigan. He received his Ph.D. from Stanford University. His interests are in social movements, social networks, and the influence of finance on society.

Michael Lounsbury (ml37@bus.ualberta.ca) is the Alex Hamilton Professor of Business at the University of Alberta School of Business and the Canadian National Institute for Nanotechnology. He received his Ph.D. from Northwestern University. His research focuses on institutional emergence and change, entrepreneurship, and the cultural dynamics of organizations and practice. 


\section{APPENDIX \\ Variable Descriptions}

\section{Variables}

Years since creation

Companies listed

Market capitalization

Exchange liberalized

Population

GDP/capita

GDP growth

Years 1990-99

Former Soviet bloc

Trade openness

Capital account balance

Domestic credit/GDP

Protestant population

French colony

Level of democracy

Left government

IMF/WB concessional aid

Measurement

Data Sources

The date of adoption is the first day of trading on a new exchange. Excluded: options exchanges, exchanges without legal provision for trading equities, countries where exchanges existed prior to independence.

Domestically incorporated companies listed on the country's stock exchanges at year end. Excludes bonds, investment companies, mutual funds, and other collective investment vehicles. Excludes foreign companies.

Share price times the number of shares outstanding for all listed domestic companies, as percentage of GDP, at market prices in current \$US.

Formal (regulative) liberalization of equity markets, defined as "[giving] foreign investors the [unrestricted] opportunity to invest in domestic equity securities" (Baekert et al., 2005: 4). Binary variable.

Natural logarithm of a country's population.

GNP at current \$US prices divided by midyear population.

Percentage of annual growth in GDP.

Dummy variable coded 1 if year $\geq 1990$ and $<$ 2001, 0 otherwise.

Countries include newly independent states of the former Soviet Union, and its sphere of influence, including members of the Warsaw Pact, Cuba, Mongolia, North Korea, and Vietnam.

Ratio is the sum of exports and imports of goods and services measured as a share of GDP.

Total credits less debits for capital transfers and nonproduced nonfinancial assets divided by GDP. IMF balance of payments definition.

Domestic credit provided to the private sector divided by GDP. Credit to private sector includes loans, purchases of nonequity securities, trade credits, and other repayable accounts receivable.

Percentage of total population in 1980 belonging to a Protestant church.

Country was part of the French colonial empire or a French protectorate prior to independence. If several colonial powers occupied a territory, we coded the latest before full independence.

Country score on the democracy scale minus its score on the authoritarian scale in Polity IV. The ten-point scales are composites taking into account constitutional and actual checks and balances and access to political participation.

Ideology (left, center, right) of country's largest party in government and its executive leader. Left ideology coded 1, right ideology -1 , both scales added.

Disbursements of loans and credits at a concessional rate by the IMF or World Bank. Concessional loans are commonly linked to structural and policy reforms, unlike nonconcessional finance, which principally meets balance of payment needs. Divided by GDP, as above.
Handbook of World Stock, Derivatives and Commodity Exchanges, 1992-2006, 1992: Blackwell; 1998-99: International Financial Publishers; 2000 on: MondoVisione, online.

World Development Indicators, 2007. Primary sources: Standard \& Poor's, Emerging Stock Markets Factbook.

World Development Indicators, 2007. Primary sources: Standard \& Poor's, Emerging Stock Markets Factbook; GNP: World Bank and OECD GDP estimates.

Dates as reported in Appendix A of Baekert et al. (2005), supplemented for additional countries from country chronologies available online at http:// www.duke.edu/ charvey/Country_risk/ couindex.htm.

World Development Indicators, 2007.

World Development Indicators, 2007.

World Development Indicators, 2007.

CIA World Factbook, own coding.

World Development Indicators, 2007.

World Development Indicators, 2007.

World Development Indicators, 2007.

LaPorta et al. (1999), data appendix (primary sources: U.N., CIA).

CIA World Factbook, 2006, own coding.

Polity IV 2004, database, University of Maryland's Center for International Development and Conflict Management: http://www.cidcm.umd.edu/polity/.

Polity IV 2004.

World Development Indicators (World Bank global development finance data). 
APPENDIX

Continued

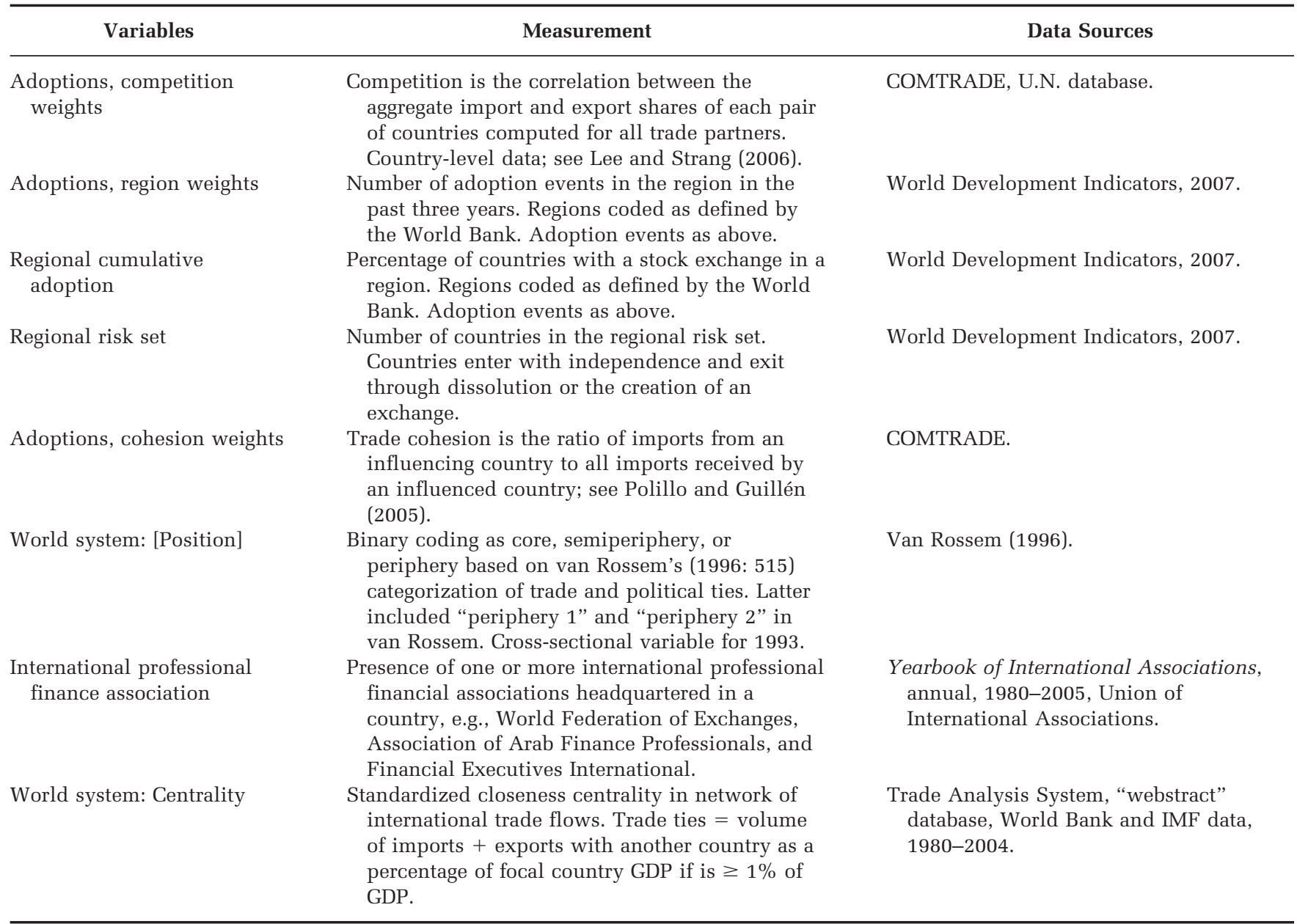

